\title{
Infection structures of fungal plant pathogens - a cytological and physiological evaluation
}

\author{
By KURT MENDGEN and HOLGER DEISING
}

Universität Konstanz, Fakultät für Biologie, Lehrstuhl für Phytopathologie, Universitätsstr. 10, D-78434 Konstanz, Federal Republic of Germany

(Received 12 November 1992)

CONTENTS

Summary

I. Introduction

II. Spore and germ tube

1. Attachment of spore and germ tube

2. Germ tube cytology

3. Production of cuticle- and cell walldegrading enzymes by hyphae

III. The appressorium

1. Induction of appressorium formation

2. The cytoplasm

3. Wall structure

4. Appressoria and the penetration process
193

193

195

195

196

198

199

199

199

200

200
IV. The penetration hypha

1. Structural aspects

2. Role of enzymes in penetration

V. The infection hypha

1. Differentiation of hypha

2. Cell wall structure

3. Cytoplasmic specialization

4. Enzyme production during differentiation of infection hypha

VI. Future prospects

Acknowledgements

References

\section{SUMMARY}

Many fungi differentiate specific infection structures in order to infect the host plant. The spore attaches to the host surface, the cuticle, and the germ tube may recognize suitable penetration sites, over which an appressorium is formed. Additional wall layers in appressoria of many fungi suggest that this structure supports increasing pressure during the penetration process. During appressorium formation, synthesis of polymer-degrading enzymes is often initiated. Cutinases, cellulases and pectin-degrading enzymes can be formed in a developmentally controlled or adaptive, i.e. substrate-dependent, fashion. The penetration hypha develops below the appressorium. This hypha has a new wall structure and exhibits features which serve to breach the plant cell wall. However, at present it is not clear whether penetration hyphae arising from appressoria are more efficient in penetration or induce less damage than hyphae which penetrate without detectable special adaptations. The infection hypha differentiates within the host. During differentiation a characteristic set of enzymes is synthesized to enable successful establishment of the host-pathogen relationship. If, as in most cases, multiple forms of cell walldegrading enzymes are formed by the pathogen, mutagenesis or deletion of a gene encoding one of these enzymes very often has no effect on pathogenicity or even virulence. Proof is missing very often that an enzyme is needed at the right time and at the right site of infection.

Events occurring during differentiation of fungal infection structures are reviewed with special emphasis on Magnaporthe grisea, Colletotrichum spp., and rust fungi, and common features which may be of importance to the success of infection are discussed.

Key words: Appressorium, cell wall-degrading enzymes, cutinase, infection hypha, Colletotrichum, Magnaporthe, rust fungi.

\section{INTRODUCTION}

Different plant organs present a variety of hurdles to potential pathogenic fungi, and successful pathogens have therefore evolved specific strategies to penetrate roots, stems, leaves or special parts thereof. Depending upon the range of plants they attack, fungal pathogens must follow more or less specialized modes of penetration and growth within the plant (DeBary, 1884; Gäumann, 1951; Wood, 1967). 

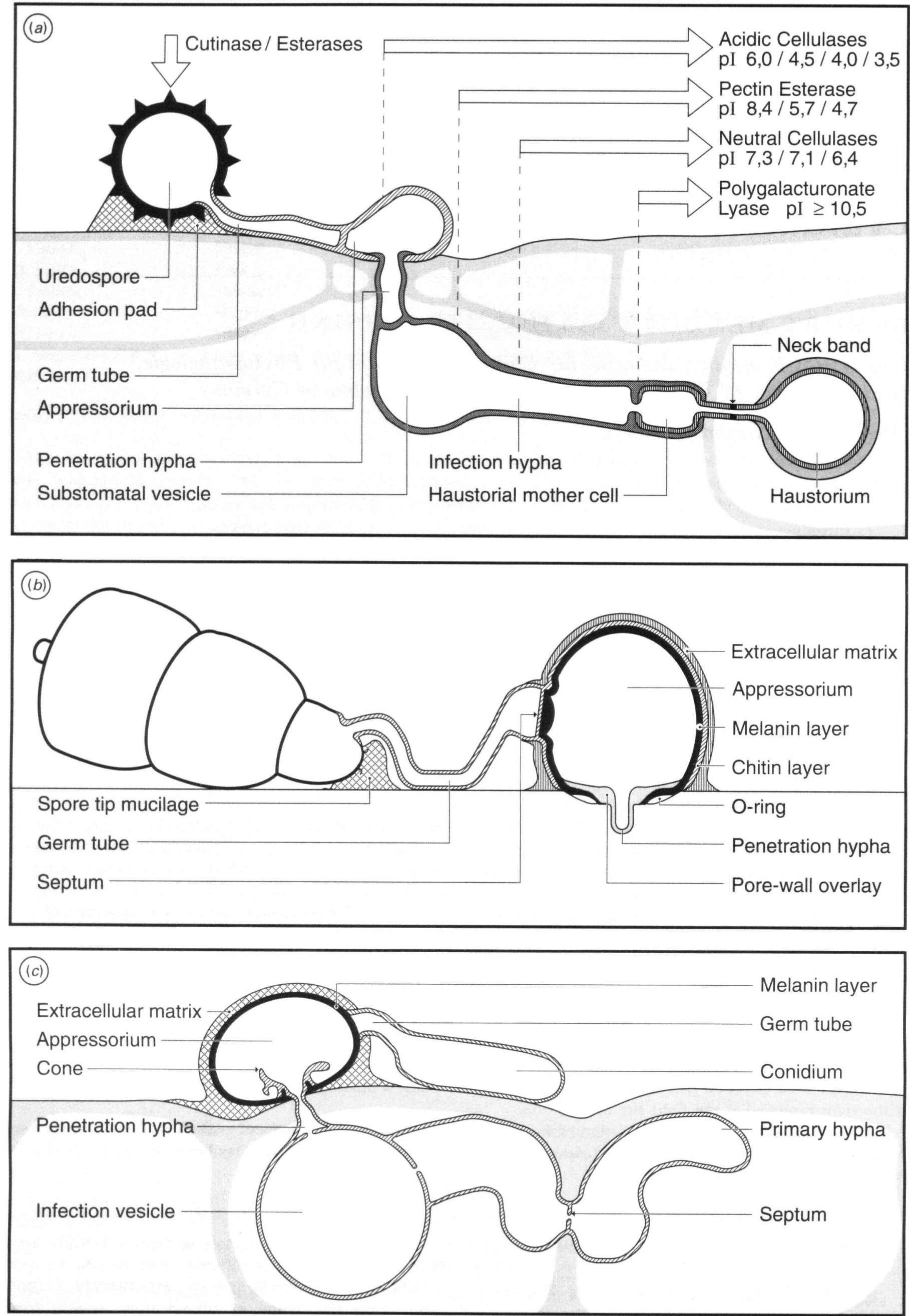

Figure 1. (a) Infection structures of Uromyces viciae-fabae. (b) Infection structures of Magnaporthe grisea (courtesy Dr R. J. Howard). (c) Infection structures of Colletotrichum lindemuthianum (courtesy Dr R. J. O'Connell). (The drawings are not to scale). 
Reviews dealing with general hyphal features, such as tip growth (Heath, $1990 a, b$, Hohl, 1992), and with infection by fungal zoospores or mycorrhizal fungi (Bonfante-Fasolo \& Perotto, 1992; Hardham, 1992), have been published recently. This review concentrates on the infection processes of selected pathogens, Colletotrichum, Magnaporthe and rust fungi. We describe the early stages of the interaction, beginning with the attachment of spores and germ tubes to the host cuticle; cytological and physiological aspects of the differentiation of appressoria, penetration hyphae and infection hyphae are discussed.

In contrast to germ tubes and appressoria differentiated on the leaf surface, penetration and infection hyphae may contact the apoplastic and perhaps even the symplastic compartment of the plant cell. At this stage, specific adaptations of the fungus for nutrient uptake and for suppression or avoidance of plant defence reactions seem to be needed. If the fungus grows successfully, the host cell may die rapidly, as in necrotrophic interactions, or after a brief benign phase, as in hemibiotrophic systems. Obligate biotrophic fungi, however, manage to maintain host cell viability for extended periods, and serve as a sink for plant metabolites. This special relationship between highly specialized fungal hyphae and host cells, tissue or organs has been called the 'aegricorpus' (Fuchs, 1976). Typical examples include the powdery mildews (Aist \& Bushnell, 1991), rusts (Bushnell, 1984) and downy mildew fungi (Hohl, 1991).

Infection structures of three fungi representing the three different trophic groups are shown in Figure 1. Uredospores of the broad bean rust fungus, Uromyces viciae-fabae, develop a series of highly specialized infection structures in order to locate the stomatal opening and to penetrate into the leaf through the stomatal pore. Spores and germ tubes adhere to the host surface, and the growing germ tube recognizes the host-specific outer ledge of stomata (Hoch et al., 1987b). This topographical signal induces appressorium formation, and subsequently a penetration hypha and an infection hypha are differentiated (Fig. $1 a$ ). After contacting a mesophyll cell, the haustorial mother cell is formed. At this stage, the biotrophic fungus breaches the host cell wall in a very subtle and highly localized fashion, thus avoiding major tissue damage, and forms a haustorium within the host cell.

Spores of Magnaporthe grisea immediately adhere to the plant surface by means of mucilage released from a compartment of the conidial apex (Hamer et al., 1988). Within $3 \mathrm{~h}$ a single, short germ tube initiates appressorium development. From this appressorium, host cell penetration starts (Fig. 1b). Subsequently, an infection hypha is produced and the plant tissue is colonized (Heath et al., 1990, 1992).

Colletotrichum lindemuthianum has a unicellular conidium which, in an aqueous environment, produces a single germ tube. Upon contact with a hard surface, the germ tube tip swells and differentiates into a thick-walled, heavily melanized appressorium. A penetration hypha arises from below the appressorium and penetrates cuticle and host cell wall. Inside the cell lumen, a globose infection vesicle develops, which in turn gives rise to a primary hypha (Fig. 1c).

In spite of numerous differences in details of infection by fungi belonging to different systematic and trophic groups, many similarities exist. This has motivated us to look for common aspects during fungal infection of host leaves and stems.

II. SPORE AND GERM TUBE

1. Attachment of spore and germ tube

Attachment of fungal spores and germ tubes to the host surface is an essential pre-infectional event which determines the success of infection (Kunoh, Nicholson \& Kobayashi, 1991 ; Nicholson \& Epstein, 1991). With respect to the differences in hydrophobicity and other features of aerial plant organs and roots, it seems logical that fungi use different mechanisms to bind to the host surface. Adhesion of fungal propagules to plant or artificial model surfaces has been described frequently (Young \& Kauss, 1984; Mendgen, Lange \& Bretschneider, 1985; Hamer et al., 1988; Hickman \& Epstein, 1988; Beckett, Tatnell \& Taylor, 1990). Adhesives analyzed so far appear to be polysaccharides, proteins, or glycoproteins (Nicholson \& Epstein, 1991), but the mechanism(s) by which adhesion is mediated is poorly understood.

Extracellular materials of some fungi have been analyzed extensively. For instance, the mucilaginous material embedding the conidia of different Colletotrichum species contains several enzymes (protease, cellulase, endo- and exo-polygalacturonase, pectin lyase, pectinesterase, invertase, $\beta$-glucosidase, peroxidase, DNase, and non-specific esterase) which may be important for infection of the host plant (Porter, 1969; Bergstrom \& Nicholson, 1981; Ramadoss \& Uhlig, 1985; Snyder \& Nicholson, 1988; McRae \& Stevens, 1990). Several of the non-specific esterases present in the mucilage of C. graminicola have been shown to exhibit cutinase activity (Pascholati et al., 1993). Cutinase, and possibly esterase activity, could theoretically alter the plant surface and produce a surface with different adhesive properties (Nicholson \& Epstein, 1991). SEM studies have shown that the cuticle underneath conidia and appressorial germ tubes of different powdery mildew fungi is structurally altered (Staub, Dahmen \& Schwinn, 1974; Kunoh et al., 1988; Nicholson et al., 1988). Nicholson, Kunoh and co-workers have applied highly concentrated extracellular material released by conidia of the obligately biotrophic 
pathogen Erysiphe graminis to the surface of barley leaves and observed erosion of those parts of the cuticle exposed to the extracellular fungal material. The extracellular material, however, exhibits not only non-specific esterase but also cutinase activity (Pascholati et al., 1992). Though these results may imply that esterases and cutinase could be involved in attachment of fungal spores to plant surfaces, proof of the involvement of these enzymes is difficult to obtain. However, Deising et al. (1992) have shown that both esterases and cutinase appear to be present in a matrix that forms an adhesion pad below uredospores of the broad bean rust fungus $U$. viciaefabae (Fig. 2). Upon contact with aqueous media the enzymes are rapidly released. These surfacelocalized enzymes have been separated by nondenaturing polyacrylamide gel electrophoresis, and a cutinase and two esterases were eluted from gels and added to autoclaved spores which, in contrast to living spores, exhibit only low levels of adhesion to broad bean (Vicia faba) cuticle. The separated cutinase and esterases were able to restore adhesion of autoclaved spores to the cuticle of broad bean leaves. Restoration of adhesion can be inhibited by the serine-esterase inhibitor diisopropylfluorophosphate (DIPF), demonstrating the specificity of the assay. These experiments on adhesion of rust uredospores have suggested a new role for esterases and cutinase in fungus-plant interactions.

Adhesive material has also been found associated with germ tubes of the rusts $U$. viciae-fabae and Puccinia hordei (Beckett et al., 1990; Read et al., 1992). When germ tubes of $P$. hordei were fractured away from the barley cuticle, wax crystals adhered tightly to the underside of the germ tube. It would be interesting to see whether or not cutinase/esterase inhibitors would alter this pattern of adhesion, as was found after inhibition of these enzymes in adhesion pads of uredospores (Deising et al., 1992).

\section{Germ tube cytology}

Germ tubes have well organized cytoplasm. Within the apical dome, a cluster of vesicles occurs in an area of cytosol generally devoid of other organelles, including ribosomes. Behind this area, numerous mitochondria are present, and nuclei follow at a constant distance from the tip. Endoplasmic reticulum (ER) and small smooth endomembrane cisternae, which may represent Golgi equivalents or typical Golgi bodies, are distributed throughout the cytoplasm except within the apex. Vesicles gather along the walls and appear to migrate towards the tip region (Heath, 1990 b; Hardham, 1992; Hohl, 1992). Most interesting is the organization of the hyphal tip. The shape of the hyphal wall is dictated by continuous apical secretion of a mixture of wall polymers which become rigid as they move outward
(Wessels, 1990). This process is thought to be mediated by the discharge of cytoplasmic vesicles from a centre in the apex, the vesicle supply centre. It probably corresponds to both the cluster of apical vesicles observed with the electron microscope and to the Spitzenkörper visible with the light microscope. A computer model confirms the correlation between vesicle production and morphogenesis in both hyphae and yeast cells (Bartnicki-Garcia, Hergert \& Gierz, 1989).

Movement of vesicles appears to be directed or mediated by the cytoskeleton. The accumulation of actin in the hyphal tip supports this assumption. In filamentous fungi, actin is associated with, and seems to radiate from, peripheral plaques (Bourett \& Howard, 1991; Roberson, 1992) or filasomes. Both can be detected either by light- or electron microscopy along the plasmalemma, forming a net close to the walls. At the hyphal tip, the actin net appears to reach into the Spitzenkörper (Bourett \& Howard, 1991). This actin net has been suggested to contribute to the firmness of the hyphal apex in the extension zone (Jackson \& Heath, 1990), the area where vesicle fusion, wall-polymer synthesis, and protein secretion occur (Förster \& Mendgen, 1987; Wessels, 1990; Wösten et al., 1991).

Recently, the force driving hyphal tip growth has attracted considerable interest. This subject is also of great importance for the function of the tip of the penetration hypha, which, as will be discussed later, represents a specialized form of the hyphal tip. Kaminskyj et al. (1992) suggest that in Saprolegnia ferax cytoskeletal factors regulate extension, at growth rates less than $12 \mathrm{~mm} \mathrm{~min}^{-1}$, in situations of lower turgor pressure, while turgor is the dominant force at high linear growth rates. Therefore, turgor pressure alone is not sufficient to explain the apical extension rate of this fungus.

The hyphal tip is extremely sensitive to any disturbance, in which case, growth stops and apical vesicles disperse immediately (Heath, 1987). Sensing and recognition of host plant features seems to occur at the hyphal tip (Hoch \& Staples, 1991). Cytological observations support this assumption. The apical vesicles are generally centrally positioned in the apical dome of the hyphal tip. However, in the germ tubes of pathogenic fungi such as Gymnosporangium juniperi virginianae, $U$. appendiculatus, and $M$. grisea they are positioned closer to the substrate ("nose down') (Mims \& Richardson, 1989; Bourett \& Howard, 1990; Kwon, Hoch \& Aist, 1991; Read et al., 1992). In addition, germ tubes of $M$. grisea and $U$. appendiculatus are flattened when in contact with the substratum and can depress the surface of a polycarbonate substrate beneath the cell (Bourett \& Howard, 1990; Kwon et al., 1991). These modifications of the hyphal tip and the pressure exerted on the substrate may reflect the 'recognition phase' of germ tubes (Mendgen et al., 1988), during which 


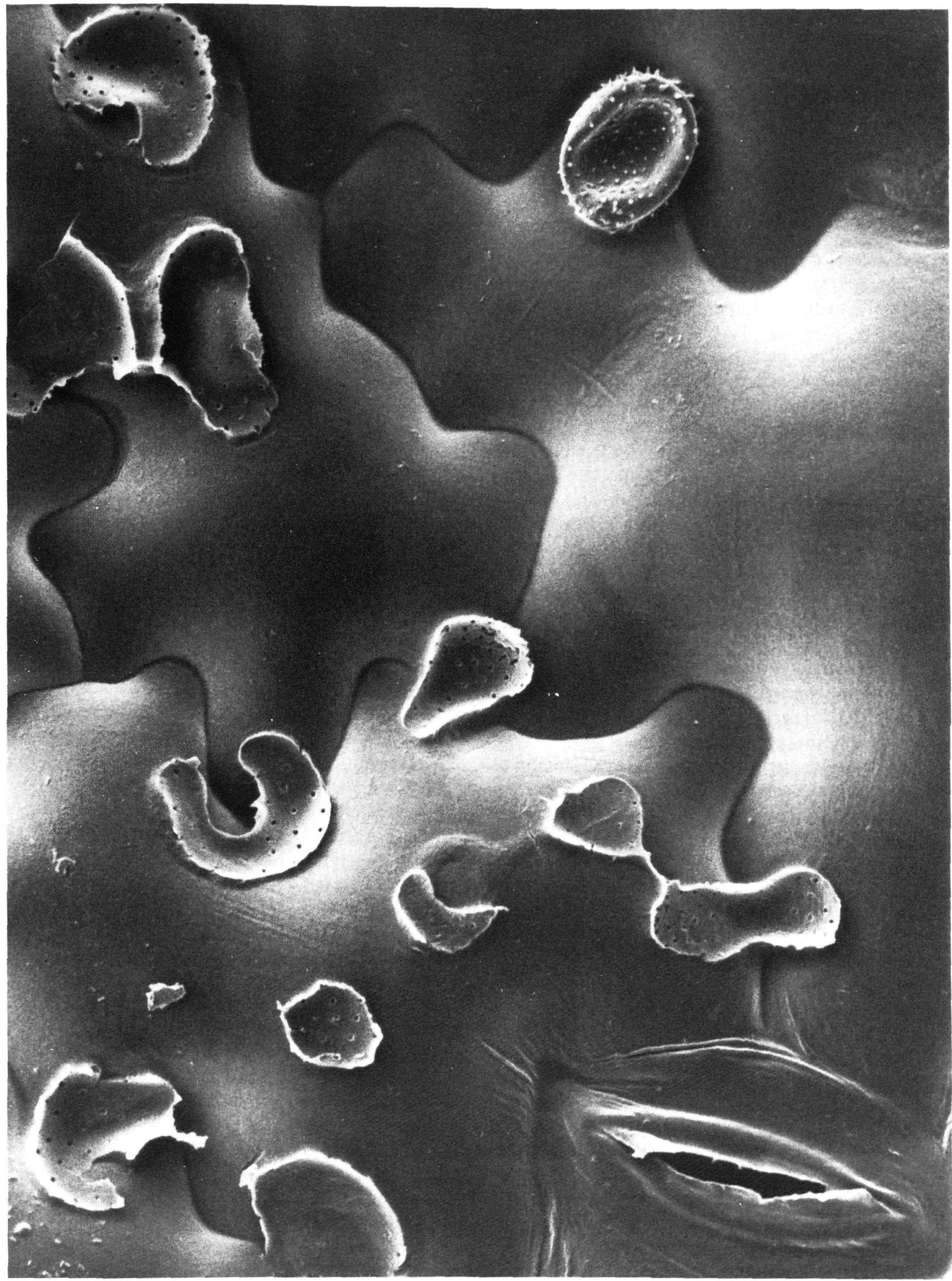

Figure 2. A view of the broad bean (Vicia faba) leaf with adhesion pads remaining on the cuticle after removal of uredospores of Uromyces viciae-fabae with an adhesive tape $(\times 2500)$.

fungi recognize physical differences in topography and rigidity of the substrate before appressoria are formed (Bourett \& Howard, 1990). The germ tube of
$U$. appendiculatus senses inductive topographies such as a stomatal opening or a precisely defined ridge of $0.5 \mu \mathrm{m}$ height over which the appressorium will be 
positioned within $4 \mathrm{~min}$ of initial contact (Hoch et al., 1987; Kwon \& Hoch, 1991). U. appendiculatus and $M$. grisea need only $40-50 \mathrm{~min}$ to form a septum that delineates the appressorium (Bourett \& Howard, 1990; Kwon \& Hoch, 1991).

\section{Production of cuticle- and cell wall-degrading enzymes by hyphae}

Germ tubes of fungi attacking aerial plant organs first contact the cuticle. Factors present in cuticle or cell wall, such as dihydroxy $\mathrm{C}_{16}$-fatty acid, 18hydroxy-9,10-epoxy $\mathrm{C}_{18}$-acid or 9,10,18-trihydroxy $\mathrm{C}_{18}$-acid, pectin, or cellulose, have been added to culture media in order to induce the formation of cutin- or cell wall-degrading enzymes in hyphae (Förster \& Rashed, 1985 ; Kolattukudy, 1985 ; Crawford \& Kolattukudy, 1987; Köller \& Parker, 1989; Urbanek, 1989; Pérez Artés \& Tena, 1990; Yazdi, Woodward \& Radford, 1990; Riou, Freyssinet \& Fevre, 1991). Although it is unclear whether or not hyphae formed in liquid culture resemble functional germ tubes, differences between cutinase formed in liquid culture and that formed on the host have not been detected with immunological techniques (Shaykh, Soliday \& Kolattukudy, 1977).

Germinating conidia of Fusarium solani f. sp. pisi (Nectria haematococca) produce low levels of cutinase activity (Kolattukudy et al., 1989, 1991). After contact with the plant cuticle, these low levels of released enzyme are sufficient to cleave ester-bonds of the cutin. Subsequently, the liberated fragments are able to induce de novo synthesis of cutinase (Woloshuk \& Kolattukudy, 1986). The gene encoding cutinase of $F$. solani has been cloned (Soliday et al., 1984), and it has been shown that plant cutin monomers, together with a protein factor of approximately $100 \mathrm{kDa}$, are necessary to initiate transcription of the cutinase gene in isolated nuclei (Podila, Dickman \& Kolattukudy, 1988). Insertion of the cutinase gene from $F$. solani into the genome of a wound pathogen of papaya fruits, the ascomycete Mycosphaerella sp., enabled this fungus to infect papaya fruits through the intact cuticle (Dickman, Podila \& Kolattukudy, 1989). Also, Köller, Allan \& Kolattukudy (1982) demonstrated that the addition of cutinase, pectinesterase, pectinase, and cellulase restored the virulence of a $F$. solani $\mathrm{f}$. sp. pisi isolate (T-30) which is almost avirulent on pea stems with intact cuticle but virulent on stems with a wounded cuticle. Correspondingly, Kolattukudy et al. (1985) reported a close correlation between cutinase production of various strains of $F$. solani f. sp. pisi and the virulence of the isolates. These results, and the fact that monospecific antibodies against cutinase from Fusarium and the chemical serine-esterase inhibitor DIPF were able to prevent infection of pea stems by F. solani f. sp. pisi (Maiti \& Kolattukudy,
1979), seem to indicate that cutinase can be regarded as a virulence factor in Fusarium, and possibly in other fungi. However, Stahl \& Schäfer (1992) created a cutinase-deficient mutant of $F$. solani f. sp. pisi by transformation-mediated gene disruption, which showed no reduction in virulence and pathogenicity in bioassays on pea, and these authors concluded that cutinase is not required for expression of pathogenicity by $F$. solani on pea. Such results are in marked contrast to data published by Kolattukudy and co-workers (Maiti \& Kolattukudy, 1979; Kolattukudy, 1985 ; Kolattukudy \& Crawford, 1987) and, thus, the question as to how much cutinase contributes to fungal pathogenicity on plants remains unclear. The question of the role of cutinase during penetration of the plant cuticle is further discussed in Section IV.2.

After breaching the cuticle, plant cell walls represent the next physical barrier to fungal pathogens (Smart, 1991). Cell wall-degrading enzymes have been analyzed from a large number of fungi, belonging to different systematic and trophic groups. Different aspects of enzymes potentially involved in cell wall degradation have been reported elsewhere (Cooper, 1983, 1984; Keon, Byrde \& Cooper, 1987), and pectin-degrading enzymes have been reviewed (Rexová-Benková \& Markovic, 1976; Collmer \& Keen, 1986). Again, the production of these enzymes has been studied during fungal growth in nutrient media, and proof that enzymes formed in vitro are identical to those produced during pathogenesis has not been presented.

Different methodological approaches have been taken to determine the importance of pectic enzymes in the expression of pathogenicity or virulence by phytopathogenic fungi, such as Sclerotinia sclerotiorum, Rhizoctonia solani, Verticillium albo-atrum, different Fusarium species, and Cochliobolus carbonum, none of which require appressoria in order to invade plant tissues. Since appressoria, at least in those cases where they are melanized, are thought to provide support for pressure applied by the infection peg, it can be assumed that cell wall-degrading enzymes are of major importance for fungi that do not differentiate appressoria. Marcus et al. (1986) detected two endo-polygalacturonase isoforms, a pectinesterase and an endo-cleaving pectin lyase in virulent isolates of $R$. solani. Pectin lyase activity could not be detected in hypovirulent isolates and this enzyme may thus be required for expression of virulence in this fungus. Likewise, studies involving chemically mutagenized $V$. albo-atrum suggests that pectinases, particularly endo-pectin lyase, may be determinants of the degree of virulence but not of pathogenicity in this fungus (Cooper \& Durrands, 1989). Uv-mutagenized strains of $F$. oxysporum $\mathrm{f}$. sp. lycopersici lacking polygalacturonase and pectinesterase activity were still pathogenic, but showed reduced virulence, on tomato (Mann, 1962). In 
studies involving 114 isolates of Sclerotinia from 23 different hosts, there was no correlation between pathogenicity and activity of pectic enzymes in vivo and in vitro (Morrall, Duczek \& Sheard, 1972). A molecular approach has been taken to elucidate the importance of endo-polygalacturonase in the infection of maize by the foliar pathogen Cochliobolus carbonum (Scott-Craig et al., 1990). The single gene encoding endo-polygalacturonase of C. carbonum was cloned, and an internal fragment of the gene was used to construct a polygalacturonase-deficient mutant of this fungus (Scott-Craig et al., 1990). Pathogenicity of the mutant on maize, however, was qualitatively indistinguishable from the wild type strain and, thus, either pectin degradation is not critical to the establishment of disease, or exopolygalacturonase activity, which was not affected by the mutation, is sufficient.

Since plant cuticle and cell wall consist of different polymers, each of which contributes to the physical barrier to be overcome by the pathogen, it appears that the available data can be easily interpreted. Thus, blocking one cuticle- or cell wall-degrading enzyme of the entire set of offensive enzymes produced by the fungus might reduce virulence but not eliminate pathogenicity. For example, two endopolygalacturonases, one endo-pectin lyase and one pectin esterase were found in Rhizoctonia solani (Marcus et al., 1986), two endo- and two exopolygalacturonases are known in Botrytis cinerea (Johnston \& Williamson, 1992) and various cellulolytic enzyme forms have been detected in different fungi (Coughlan \& Ljungdahl, 1988). Mutations in genes encoding pectic enzymes of fungi which produce only one pectic depolymerase, as has been reported for Ascochyta rabiei (Tenhaken \& Barz, 1991), the hemibiotroph Venturia inaequalis (Valsangiacomo \& Gessler, 1992), and the biotroph $U$. viciae-fabae (Deising \& Mendgen, 1992), might be expected to have a more pronounced effect on virulence or even on pathogenicity.

\section{THE APPRESSORIUM}

\section{Induction of appressorium formation}

Since the first study by Büsgen (1893) on the influence of the stomatal pore on the induction of appressoria in rust fungi, numerous experiments have been carried out to characterize stimuli and mechanisms active in appressorium induction and formation. It has been shown that a broad variety of leaf surface features or chemical substances of the plant may either induce germination or stop growth of the hyphal tip and induce appressorium formation (Carver \& Ingerson, 1987; Allen et al., 1991; Chapela, Petrini \& Hagmann, 1991 ; Hoch \& Staples, 1991). Inductive signals can be extremely heterogeneous, even for fungi that infect only plant leaves. In rust fungi, chemical stimuli include metabolites extracted from uredospores (Macko, Renwick \& Rissler, 1978), volatiles from the host plant (Grambow, 1977), ions such as $\mathrm{K}^{+}$or $\mathrm{Ca}^{2+}$, sucrose (Kaminskyj \& Day, 1984; Hoch \& Staples, 1987; Stumpf et al., 1991), cyclic nucleotides, or stimulators of adenylate cyclase (Hoch \& Staples, 1984). Potassium ions stimulate appressorium formation at $\mathrm{pH} 7 \cdot 0$, even when the germ tubes grow aerially, away from the substrate (Hoch, Staples \& Bourett, 1987). In addition, topographical signals such as scratches or precisely defined ridges on a membrane (Hoch et al., 1987), or a 'heat shock' (Maheswari, Hildebrandt \& Allen, 1967), induce formation of appressoria. The mechanisms by which a hyphal tip could sense minute surface features may include the different components of the cytoskeleton and/or an ionic or electric change mediated by mechanosensitive channels (Read et al., 1992). Both possibilities have been tested (Hoch \& Staples, 1991; Zhou, Stumpf \& Hoch, 1991) but conclusive explanations of the signal transduction pathway are not yet available.

\section{The cytoplasm}

In uredosporelings of $U$. appendiculatus, $U$. viciaefabae, Phakopsora pachyrhizi and in aeciosporelings of Arthuriomyces peckianus, nuclear division is strictly correlated with appressorium development, including septum formation (Kapooria \& Mendgen, 1985; Koch \& Hoppe, 1988; Kwon \& Hoch, 1991; Swann \& Mimms, 1991). The fine structure of these nuclei and the structure of the spindle pole body is comparable to that of other rust fungi (Swann \& Mims, 1991). In M. grisea and in Colletotrichum, division occurs soon after germination, with one nucleus remaining in the conidium while the other migrates into the incipient appressorium (Howard, Bourett \& Ferrari, 1991; Bailey et al., 1992).

Most interesting is the behaviour of the cytoplasmic vesicles, which resemble apical vesicles, during initiation of appressorium formation. They are concentrated near the substrate in a position where they could be influenced by minor irregularities in surface topography, such as a ridge or stomatal pore (Kwon et al., 1991). As the appressorium matures, numerous vesicles of different size and unknown origin gather at the penetration pore, where the tip of the penetration hypha will develop (Mims \& Richardson, 1989; Howard et al., $1991 a$; Swann \& Mimms, 1991). Kwon et al. (1991) suggest that this redistribution of vesicles is guided by the microtubule and (or) $\mathrm{F}$-actin microfilament cytoskeleton. Initially, cytoskeletal elements in developing appressoria of $U$. appendiculatus become arranged randomly during contact with the inductive ridge in the substrate. Subsequently, many cytoskeletal elements are orientated in parallel to the ridge. Further from the substrate, microtubules and 
microfilaments are arranged in a reticulate pattern, mostly close to the appressorial wall, with peripheral plaques or the actin-containing filasomes adjacent to the plasma membrane (Bourett \& Howard, 1991; Kwon et al., 1991). Additional studies are needed to elucidate the behaviour of the cytoskeleton during the subsequent development of the penetration hypha. It would be interesting to know whether there are similarities to the budding site in yeasts, where a ring of filaments is observed (Kim, Haarer \& Pringle, 1991).

\section{Wall structure}

As with spores and germ tubes (Kunoh et al., 1991; Nicholson \& Epstein, 1991), appressoria are firmly attached to their substrate. Extended exposure to ultrasonication may destroy appressoria of $M$. grisea and $C$. lindemuthianum completely, but their wall in contact with the substrate remains intact and attached (Uchiyama et al., 1979; Howard et al., $1991 a$; R. J. O'Connell, unpublished results). Adhesion seems to be mediated by a mucilaginous substance covering all fungal appressoria, which can be seen with an electron microscope after proper processing (Hoch, 1991; Read, 1991). This material is gel-like and forms a thin layer on top of the appressorium, accumulates laterally and tapers off below the appressorium of $M$. grisea and many other fungi (Mims \& Richardson, 1989; Howard et al., $1991 a$; Swann \& Mims, 1991; Van Dyke \& Mims, 1991). The matrix around appressoria of Colletotrichum spp. contains $\beta$-1,4-linked $N$-acetylglucosamine, $\alpha$-linked $N$-acetylgalactosamine or galactose, and $\alpha$-linked mannose or glucose (O'Connell, Nash $\&$ Bailey, 1992).

In cross-sections, wheat germ agglutinin (WGA) labelled the outer wall layer, but not the inner wall layer or the appressorial cone (O'Connell \& Ride, 1990). Similarly, in appressoria of $M$. grisea, only the outer wall layer has affinity to WGA, indicating that this layer has a high chitin content. Colletotrichum spp. and $M$. grisea, in addition, produce melanized appressorial walls (Wolkow, Sisler \& Vigil, 1983; Woloshuk, Sisler \& Vigil, 1983; Kubo, Furusawa \& Shishiyama, 1987; Howard \& Ferrari, 1989; Van Dyke \& Mims, 1991).

Affinity to lectins changes during maturation of appressoria of $U$. viciae-fabae, $M$. grisea and $C$. lindemuthianum (Kapooria \& Mendgen, 1985; Howard et al., $1991 a$; O'Connell, 1991). This suggests that either new wall layers are added to the appressorium or the matrix around appressoria becomes so dense, because of the addition of other constituents, that lectins no longer have access to their haptens.

Appressorial walls of the rust fungi $P$. graminis $\mathrm{f}$. sp. tritici and $U$. viciae-fabae are thicker than the respective germ-tube walls. The increased thickness is due to an additional inner layer with more abundant chitin fibrils (Harder et al., 1986; Freytag \& Mendgen, 1991b). The haustorial mother cells of rust fungi, probably an internal equivalent of appressoria, also develop additional internal wall layers (Heath \& Heath, 1975; Chong, Harder \& Rohringer, 1985). As with appressoria, increased chitin density (Freytag \& Mendgen, 1991b) was detected with WGA over haustorial mother cells of $U$. viciae-fabae after removal of the outer layers with enzymes.

The appressorial surfaces of $P$. graminis f. sp. tritici, $P$. coronata, $U$. appendiculatus, $U$. viciae-fabae (mono- and dikaryotic stages) and U. rumicis (monoand dikaryotic stages) bind WGA, pokeweed (Phytolacca americana) mitogen (PWM) and, to a lesser extent, Concanavalin A (ConA), which suggests the presence of chitin and mannose or glucose (Holden \& Strange, 1985; Mendgen et al., 1985; Heath, 1989; Freytag \& Mendgen, 1991b). Additionally, appressoria of $U$. rumicis bind to Lotus tetragonolobus agglutinin (LTA), suggesting the presence of fucose (Freytag, 1990). In cross sections, however, affinity to WGA is evident only in the inner walls of appressoria (Ebrahim-Nesbat, Hoppe \& Rohringer, 1985; Harder et al., 1986). This may indicate that lectins either penetrate through the outer surface matrix in these light microscopical studies, as was the case with germ tubes of $P$. sorghi (Chaubal, Wilmot \& Wynn, 1991), or that chitin cannot be detected in the outer layer with lectin-gold labelling in the electron microscope because chitin was inaccessible to WGA. Removal of the outer matrix from appressoria of $U$. viciae-fabae, with pronase, $\alpha$ and $\beta-(1,3)$ glucanase or $\mathrm{NaOH}$, increased affinity to WGA about 3- to 6-fold, and to Lens culinaris agglutinin (LCA) and ConA about 2-fold (Freytag, 1990). It was concluded that appressoria of rust fungi have a thick chitin wall (other constituents have not been defined yet) that is covered by a matrix consisting of glycoproteins into which $\alpha$ - and $\beta$-1,3glucans and chitin extend (Freytag \& Mendgen, $1991 b)$.

\section{Appressoria and the penetration process}

Numerous factors may contribute to the success of the penetration process. As mentioned before, appressoria attach firmly to their substrate by means of extracellular adhesives or, above stomatol pores, appressoria of many rust fungi get hold by wedging their base between the outer ledge of the stomatal opening (Mendgen, $1973 a$; Davies \& Butler, 1986; Mims, Taylor \& Richardson, 1989). The latter appressoria detach easily from their substrate if they are produced on artificial membranes because the infection peg is able to lift the appressorium from the substrate (Deising, Jungblut \& Mendgen, 1991).

In $M$. grisea, a thick layer reinforced with melanin 
reduces the porosity of the wall of the appressorium in order to build up high turgor pressure therein (Howard \& Ferrari, 1989; Chumley \& Valent, 1990). Measuring the wall porosity of wild type and of melanin-deficient mutants of $M$. grisea, both of which have chitin, clearly showed that the reduced porosity is due to melanin. In $M$. grisea, and also in C. lagenarium, melanin is synthesized via scytalone. Mutants with deficiencies in this pathway, or wildtype isolates treated with fungicides acting as inhibitors of melanin biosynthesis, lack the melanin layer and cannot infect the host plant (Wolkow et al., 1983; Woloshuk et al., 1983; Kubo et al., 1987; see Kubo \& Furusawa, 1991, for review). Changes in the cytoplasm also support appressorial function. The disappearance of accumulated glycogen during the increase of turgor suggests a correlation between these two events. In addition to changes in the permeability of walls, and possibly also the plasma membrane, an increase in the concentration of glycogen degradation products may result in development of pressures up to 80 bars $(8.0 \mathrm{MPa})$ in the interior of appressoria of $M$. grisea (Howard et al., 1991b). Such pressure seems to contribute significantly to the indentation of the cuticle or artificial membranes by appressoria of $M$. grisea and sustains the progress of the penetration peg as will be discussed later (Woloshuk et al., 1983; Howard et al., $1991 b$ ).

The penetration pore, an area free of wall material and melanin, is observed at the base of appressoria of many Colletotrichum spp. and in M. grisea (Marks, Bergee \& Riker, 1965; Politis \& Wheeler, 1973; Bourett \& Howard, 1990; Howard et al., $1991 a$; Van Dyke \& Mims, 1991). A similar wall-less area has also been found in some rust fungi, such as $G$. juniperi-virginianae and A. peckianus (Mims \& Richardson, 1989; Swann \& Mims, 1991). Thus, pressure can be focused effectively in this part of the appressorium. The pore is surrounded by a ring-like structure in $M$. grisea, which seems to seal or to strengthen the border of this pore (Howard et al., 1991a). In many, but not in all Colletotrichum species, an appressorial cone, which represents a new wall structure, is produced around the pore (Brown, 1977; Landes \& Hoffmann, 1979; Xuei, Järlfors \& Kuć, 1988; Mould, Boland \& Robb, $1991 a$; O'Connell \& Bailey, 1991). A similar structure is found in appressoria of other fungi which penetrate directly, e.g. Venturia inaequalis (Spilocea pomi) (Corlett \& Chong, 1977), in basidiospore-derived appressoria of some rusts (Metzler, 1982; Gold \& Mendgen, 1984; Mims \& Richardson, 1989), and in uredospore- or aeciospore-derived appressoria of the direct-penetrating rusts, $P$. pachyrhizi and $A$. peckianus (Koch, Ebrahim-Nesbat \& Hoppe, 1983; Swann \& Mims, 1991). C. truncatum, C. graminicola and $M$. grisea produce only a pore overlay from which the penetration hypha develops (Politis \&
Wheeler, 1973; Bourett \& Howard, 1990; Howard et al., 1991 a; Van Dyke \& Mims, 1991).

The variability in structure of the appressorial wall and the penetration zone suggests that fungi follow different strategies to pierce the plant cell wall. Basidiospores of $U$. appendiculatus penetrate mostly starting from appressoria, but sometimes penetrate directly with a very short germ tube (Gold \& Mendgen, 1984). Uredosporelings from $P$. striiformis do not seem to produce appressoria at all (Opel, Schmidt \& Wolfgang, 1986). Appressoria of uredosporelings from rust fungi which penetrate through stomata do not develop cones as do rusts that penetrate directly (Koch et al., 1983; Hoppe \& Koch, 1989; Van Dyke \& Mims, 1991). But there are also many other fungi that penetrate the epidermis directly without producing appressorial cones (Aist \& Bushnell, 1991; Swann \& Mims, 1991).

\section{THE PENETRATION HYPHA}

\section{Structural aspects}

The penetration hypha is a specialized hypha produced by the fungus to penetrate the stomatal opening or the host cell wall. The term penetration hypha includes the terms penetration peg and infection peg. The wall of the penetration hypha appears continuous with the wall material that accumulates around the pore at the base of mature appressoria, i.e. the wall overlay or the appressorial cone. This has been demonstrated for Colletotrichum spp., M. grisea and certain rust fungi (Politis \& Wheeler, 1973; Koch et al., 1983; Chong et al., 1985; Mims \& Richardson, 1989; Howard et al., $1991 a$; O’Connell \& Bailey, 1991; Swann \& Mims, 1991).

The main problem in the study of the penetration hypha is the difficulty of properly processing infected tissue for electron microscopy (Mendgen et al., 1991). The fungal wall is very thin in this area and the stains currently used do not easily differentiate between fungal and host plant walls. In addition, the staining properties of fungal walls are poor, the embedding resin tends to separate at the junction between the two walls, and it is difficult to get a good median section of the thin penetration hypha (Hoch, 1977; Hoch, 1991). Considerable progress in the study of infection structures has been obtained in the last few years by using freeze substitution techniques (Mims \& Richardson, 1989) and cytochemical tests (Harder \& Chong, 1991). The latter method has allowed the fate of specific wall layers to be followed during fungal development. Lectins have proven to be valuable probes, especially for the detection of chitin. By using a WGA-ovomucoid gold complex as a probe for chitin, the sensitivity of the assay has been improved considerably. Using this probe, chitin was detected in the walls of 
the penetration hypha of Sphaerotheca pannosa, a powdery mildew fungus (Hajlaoui, Benhamou \& Bélanger, 1992).

The penetration hypha of $M$. grisea and $C$. lagenarium is small in diameter compared to the pore (Katoh et al., 1988; Howard et al., 1991a). This suggests that forces other than turgor pressure alone are responsible for the extension of the tip of the penetration hypha. $M$. grisea accumulates apical vesicles and actin in a defined area of the pore and thus seems to define the diameter of the penetration hypha (Bourett \& Howard, 1992). Many fungi define the diameter and length of the penetration hypha without being influenced by the host. Basidiospores of rust fungi produce such structures of a similar size on agar (Freytag et al., 1988; Gold \& Mendgen, 1991 ) or, in the case of uredospores, on a wide range of artificial membranes and even after thermoinduction of infection structures (Dickinson, 1949; Mendgen, 1982; Hoch \& Staples, 1987).

The vesicles in the tip of the penetration hypha are of different size and staining properties (Mims \& Richardson, 1989; Swann \& Mims, 1991; Van Dyke \& Mims, 1991; Bourett \& Howard, 1992). Some vesicles may contain cuticle- and cell wall-degrading enzymes, because smooth membranous elements similar to Golgi equivalents pinch off such vesicles (Mendgen, 1989; Hoch, 1991).

Recent experiments have shown that the penetration hypha, though thin-walled, is a very rigid structure. In spite of the very high pressure in the appressorium of $M$. grisea, the penetration hypha remains a well defined slender tube and does not extend in all directions after growing out of the appressorium and during development in a cellulose membrane (Howard et al., $1991 a, b$; Bourett \& Howard, 1992). Within the cuticle and in the host wall, the diameter of the penetration hypha of $M$. grisea is more variable (Woloshuk et al., 1983; Heath et al., 1992). The penetration hypha of $C$. lindemuthianum is very narrow $(c .100 \mathrm{~nm})$ where it penetrates the cuticle and widens to approximately $500 \mathrm{~nm}$ during penetration of the periclinal cell wall (O'Connell \& Bailey, 1991). The cytoplasm in the apex of the penetration hypha of $M$. grisea consists primarily of an exclusion zone, excluding even ribosomes. Actin and some apical vesicles are the main constituents and seem to play an important role in defining the dimensions and, possibly also, growth orientation of the penetration hypha (Bourett \& Howard, 1992). In cases where a penetration hypha of $C$. lindemuthianum or C. trifolii meets an anticlinal wall, the tip changes direction within the epidermis to reach the protoplast (Landes \& Hoffmann, 1979; Mould et al., 1991a; Mould, Boland \& Robb, 1991b). Papilla formation in systemically protected cucumber may block the penetration hypha of $C$. lagenarium and induce swelling or branching of the hypha tip in $C$. graminicola and C. lindemuthianum (Politis \& Wheeler, 1973; Xuei et al., 1988; R. J. O’Connell, unpublished results).

There is no evidence yet, however, that penetration hyphae arising from appressoria are more efficient in penetration, or induce less damage to the host plant, than hyphae which seemingly penetrate without special adaptations. Rust fungi provide a good example. In the dikaryotic stage, sophisticated appressoria and a penetration hypha with specialized walls develop (Koch et al., 1983; Mims \& Richardson, 1989; Swann \& Mims, 1991). During intercellular growth, very specialized haustorial mother cells, which insert haustoria into the plant cell, differentiate (Harder \& Chong, 1991). In contrast, in the monokaryotic stage, appressoria are barely developed and only the penetration hypha is specialized (Gold \& Mendgen, 1984; Mims \& Richardson, 1989). During subsequent growth within the host tissue, monokaryotic hyphae are constricted during penetration, but fungal walls do not exhibit obvious specialization during penetration of the host wall (Chong, Harder \& Rohringer, 1981; Gold \& Mendgen, 1991; Harder \& Chong, 1991). Both stages may parasitize the same host, and the reason for the different degrees of complexity of the infection structures is not clear. In Ustilago maydis, where hyphae are formed after sporidial fusion, poorly differentiated appressoria are produced and host epidermal cells are invaded with a barely specialized penetration hypha. Walls of appressoria and of penetration hyphae appeared to be distinct only in their staining properties (Snetselaar \& Mims, 1992).

The apex of the penetration hypha is possibly the first part of the fungus to contact the host plasma membrane. Yet no clear evidence is available to show that plasma membranes of host and filamentous fungi really come into contact at this stage of infection. It seems that at least a wall of the fungus, or some extracellular material from the parasite and/or the host, separates both partners. In any case, critical steps for recognition may occur as soon as the penetration hypha reaches the plant protoplast (Hohl, 1991). Fungal elicitors present on the surface of the pathogen may be released to bind to receptors on the plant plasma membrane (Cosio et al., 1990; Cheong \& Hahn, 1991). In order to study processes involved in recognition, protoplasts from isolated mesophyll cells were brought into contact with hyphae of Phytophthora infestans grown on nutrient media (Hohl \& Balsiger, 1986). Mannosyl-glucosyl and galactosyl/ $\mathrm{N}$-acetylgalactosyl residues were found on the surface of soybean protoplasts (Odermatt et al., 1988). However, evidence for the involvement of specific glycoproteins of the fungus in adhesion or recognition has not been found (Odermatt et al., 1988). One possible reason seems to be that the area of the fungus in contact with host plasma membrane may be restricted to the tip of the 
penetration hypha. This zone would be very small and not available for biochemical analysis.

\section{Role of enzymes in penetration}

The role played by cutinase in penetration by fungi forming appressoria has been examined in remarkably few cases. The necrotrophic pathogen of papaya, C. gloeosporioides, and that of rice and other gramineae, $M$. grisea, as well as the hemibiotrophic apple scab fungus, $V$. inaequalis, all produce cutinase when growing on media containing cutin as the sole carbon source (Dickman, Patil \& Kolattukudy, 1982; Köller \& Parker, 1989; Sweigard, Chumley \& Valent, 1992a). Electron microscopy, using monospecific antibodies to localize the enzyme, has shown that the enzyme is secreted by the fungus during the penetration process (Kolattukudy \& Crawford, 1987). Inhibition studies, using DIPF or antibodies to cutinase, suggest an essential role of cutinase in early infection processes by Colletotrichum (Dickman, Patil \& Kolattukudy, 1983; Pascholati et al., 1993), Venturia (Köller, Parker \& Becker, 1991) and F. solani f. sp. pisi (Maiti \& Kolattukudy, 1979). However, contrary evidence has been presented for certain Colletotrichum spp. (Bonnen \& Hammerschmidt, 1989; Bailey et al., 1992).

Recently, the cutinase gene of the rice blast fungus, $M$. grisea, has been cloned (Sweigard et al., 1992a), and the gene has been disrupted in two strains of the pathogen (Sweigard, Chumley \& Valent, 1992b). In these strains, pathogenic on weeping lovegrass (Eragrostis curvula) and barley or rice, cutinase transcripts were not detectable. However, enzyme activity measured with tritiated cutin or $p$-nitrophenyl butyrate was not completely eliminated. Mutant and wild-type strains were used to infect the three host plants, and the lesions produced by the mutants were indistinguishable from those of the parental strains. The authors concluded that the cutinase gene of $M$. grisea is not required for pathogenicity. However, since the mutants still showed some cutinase and esterase activity, it is possible that not all cutinase genes actually present in the genome of the rice blast fungus were disrupted and that the probe used to detect cutinase transcripts did not show sufficient homology with the mRNA of non-disrupted cutinase genes.

The question as to whether penetration of host cell walls is facilitated by enzymes, by mechanical forces, or by a combination of both, has been a subject of controversy for many years, especially with respect to obligately biotrophic fungi (Smith, 1900; Waterhouse, 1921; Brown \& Harvey, 1927; Van Sumere, Van Sumere-De Preter \& Ledingham, 1957; McKeen, Smith \& Bhattacharya, 1969; Takahashi, Aist \& Israel, 1985; Deising \& Mendgen, 1992). McKeen et al. (1969) investigated the involvement of enzymes in penetration of plant epidermal cell walls by different powdery mildew fungi by cytochemical techniques. The authors demonstrated alterations of the epidermal wall of barley, clover, strawberry, and sunflower occurring around the infection peg of $E$. graminis, E. polygoni, Sphaerotheca macularis, and E. cichoracearum, respectively, while the peg grew through the wall. Differential extraction and staining of the polysaccharides of the cell wall suggested that cellulose around the infection peg of the obligate biotroph was enzymatically degraded.

In urediosporelings of the biotroph $U$. viciaefabae, formation of cellulolytic enzymes is regulated in a strictly differentiation-specific manner (Heiler, Mendgen \& Deising, 1993). A group of acidic cellulases (pIs $3 \cdot 5,4 \cdot 0,4 \cdot 5$, and $6 \cdot 0$ ) is formed after perception of a thigmotrophic stimulus without substrate being present, and the start of enzyme formation at $7 \mathrm{~h}$ after inoculation (p.i.) of inductive polyethylene membranes correlates with appressorium formation (Fig. $3 a$ ). The formation of these enzymes continues during later stages of infection structure differentiation, i.e. when penetration hypha, infection hypha and haustorial mother cells are formed (Heiler et al., 1993). Since penetration by this rust fungus does not occur directly, the importance of cellulases at this pre-penetration stage of fungus-plant interaction is unclear. At later stages, cellulolytic enzymes might be involved in localized dissolution of the host cell wall (see Section V.4).

Suzuki et al. (1982) showed that treatment of nonmature, non-pigmented appressoria of the necrotroph $C$. lagenarium with the protein synthesis inhibitor cycloheximide prevented formation of the penetration hypha and formation of halos on cellulose membranes, which indicates enzymatic dissolution. Subsequent studies (Suzuki, Furusawa \& Yamamoto, 1983; Katoh et al., 1988) have demonstrated that a $95 \mathrm{kDa}$ protein, presumably a cellulase, is synthesized specifically during differentiation of appressoria, and that this enzyme is involved in penetration of cellulose membranes and may also play a nutritional role during the penetration process. Also, the dissolution of cell walls of Phaseolus vulgaris by the hemibiotroph $C$. lindemuthianum is highly localized and enzymatic degradation seems to be restricted to the site of penetration of the epidermal wall. Several microscopical investigations have been carried out on the infection process (Wheeler, 1975; O'Connell, Bailey \& Richmond, 1985), but evidence for the involvement of wall-degrading enzymes at this stage of infection is only circumstantial at present.

Obviously, the different strategies for penetration are highly adapted to conditions presented by the host plant, e.g. thickness of waxy or cuticular layers. Furthermore, the more pressure is produced in the appressorium, the less enzymes may be needed to pierce the cuticle and the plant cell wall. These 

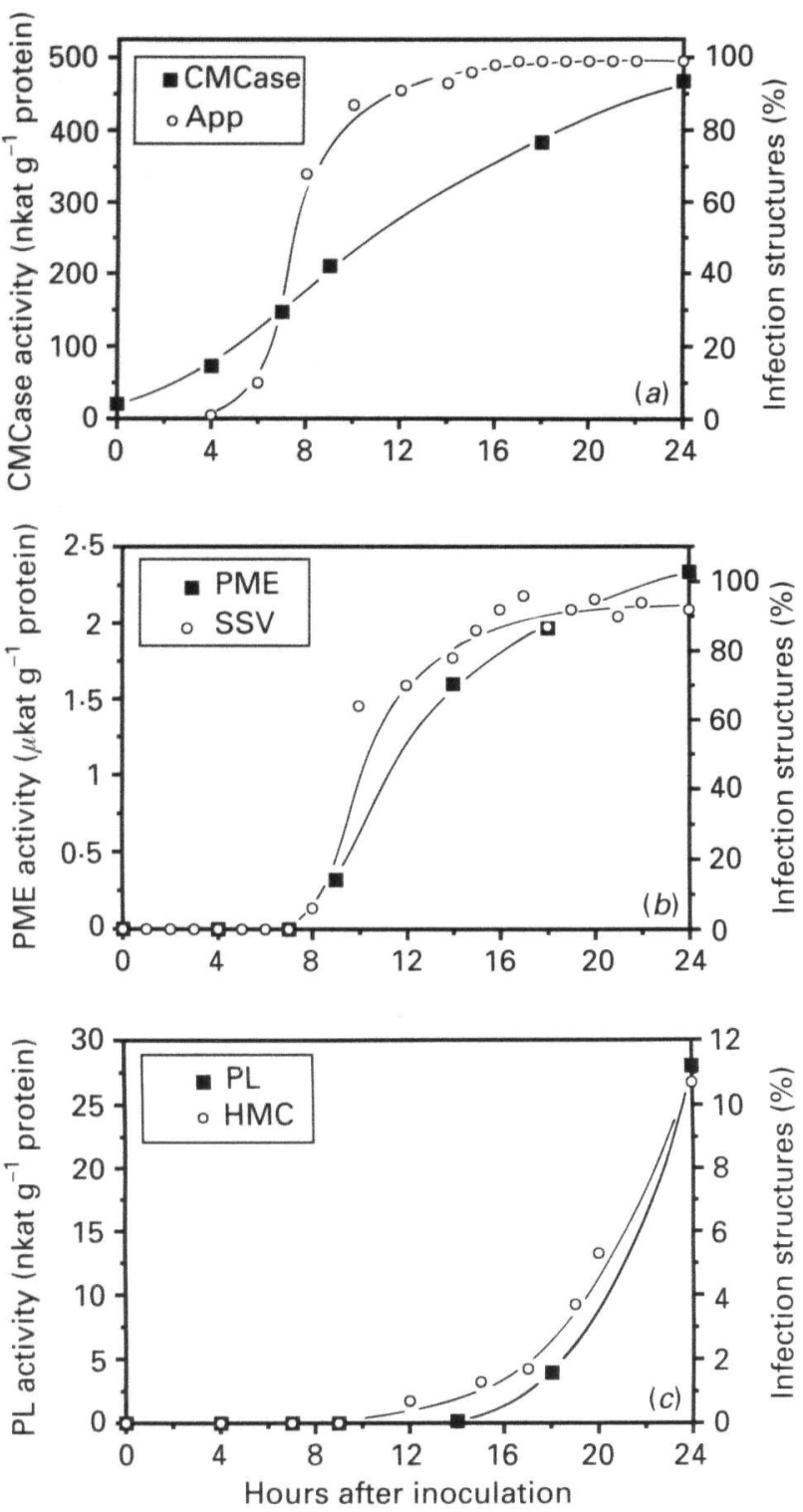

Figure 3. Correlation between the differentiation of infection structures and the production of cell walldegrading enzymes in Uromyces viciae-fabae. (a) Cellulases, measured as carboxymethyl cellulase (CMCase) activity and the appearance of appressoria (App). (b) Pectinmethylesterase (PME) activity and formation of substomatal vesicles (SSV), which represent young infection hyphae. (c) Polygalacturonate lyase (PL) activity and formation of haustorial mother cells (HMC) (the substrate of PL was applied to spores). The data shown are means of three independent experiments.

features seem to be typical for each fungal species and do not necessarily determine the final outcome of infection. Basidiospores of $U$. vignae can penetrate the non-host cuticle of Vicia faba much faster and with higher efficiency than the host epidermis, but the infection is stopped a few hours later within the cytoplasm (Xu \& Mendgen, 1991).

\section{v. THE INFECTION HYPHA \\ 1. Differentiation of hypha}

Especially in cases where host cells survive infection for a considerable time, very specific differentiation of hyphae occurs during intercellular or intracellular growth. The newly differentiated hypha in the host, the infection hypha, which represents an elongation of the penetration hypha, seems to be a distinct morphological unit with special physiological functions. As a first step of fungal development within the cell or the substomatal cavity, a globose infection vesicle often develops (Fig. $4 a$ ), which subsequently elongates to a hypha, called a primary hypha or infection hypha. We think that the vesicle, with its elongation, form one unit and may be regarded as a functional infection hypha. In addition to morphological studies in planta, a physiological characterization of these specialized hyphae is possible because some fungi such as rusts, $M$. grisea, Colletotrichum species, and to a certain extent also the grapevine powdery mildew, Uncinula necator (Dickinson, 1949; Staples et al., 1985; Freytag et al., 1988; Blaich, Heintz \& Wind, 1989; Howard et al., $1991 a$; O'Connell \& Bailey, 1991) can be induced to produce their infection hyphae under artificial conditions. Some rust fungi also differentiate haustorial mother cells in the absence of host cells (Heath \& Perumalla, 1988; Deising et al., 1991; Freytag \& Mendgen, 1991a). Sometimes, even the differentiation of haustoria can be induced in the absence of the host plant (Heath, 1989; Freytag, 1990; Heath, 1990). Thus, fungal development can be studied step by step in vitro. Infection structures from rust fungi produced on inductive membranes have an identical morphology to those structures produced in the leaf. Nuclear division and nuclear behaviour also appear identical to events occurring in the leaf (M. Stark-Umau, Konstanz, unpublished result). But not all fungi produce identical infection structures in vitro and in vivo. C. lindemuthianum germlings developed in vitro, on Formvar membranes, did not produce the appressorial cone. The hyphae emerging from such appressoria had much higher affinity to WGA and were morphologically distinct from intracellular infection hyphae, resembling instead the filamentous hyphae produced in culture (O'Connell \& Ride, 1990; O'Connell \& Bailey, 1991). Therefore, interpretation of results with infection hyphae produced in vitro should be done with care.

\section{Cell wall structure}

Evidence from morphological observations, cytochemical tests and staining with heavy metals suggests that the walls of infection vesicles and infection hyphae are continuous with that of the penetration hypha in fungi such as $M$. grisea, many Colletotrichum species, and rusts (Ebrahim-Nesbat et al., 1985; Howard et al., 1991 a; O'Connell \& Bailey, 1991). This wall is probably modified in order to sustain the acceptance of the host plant during the infection process.

$M$. grisea differentiates a penetration hypha and an infection hypha within cellophane. Unlike the walls 


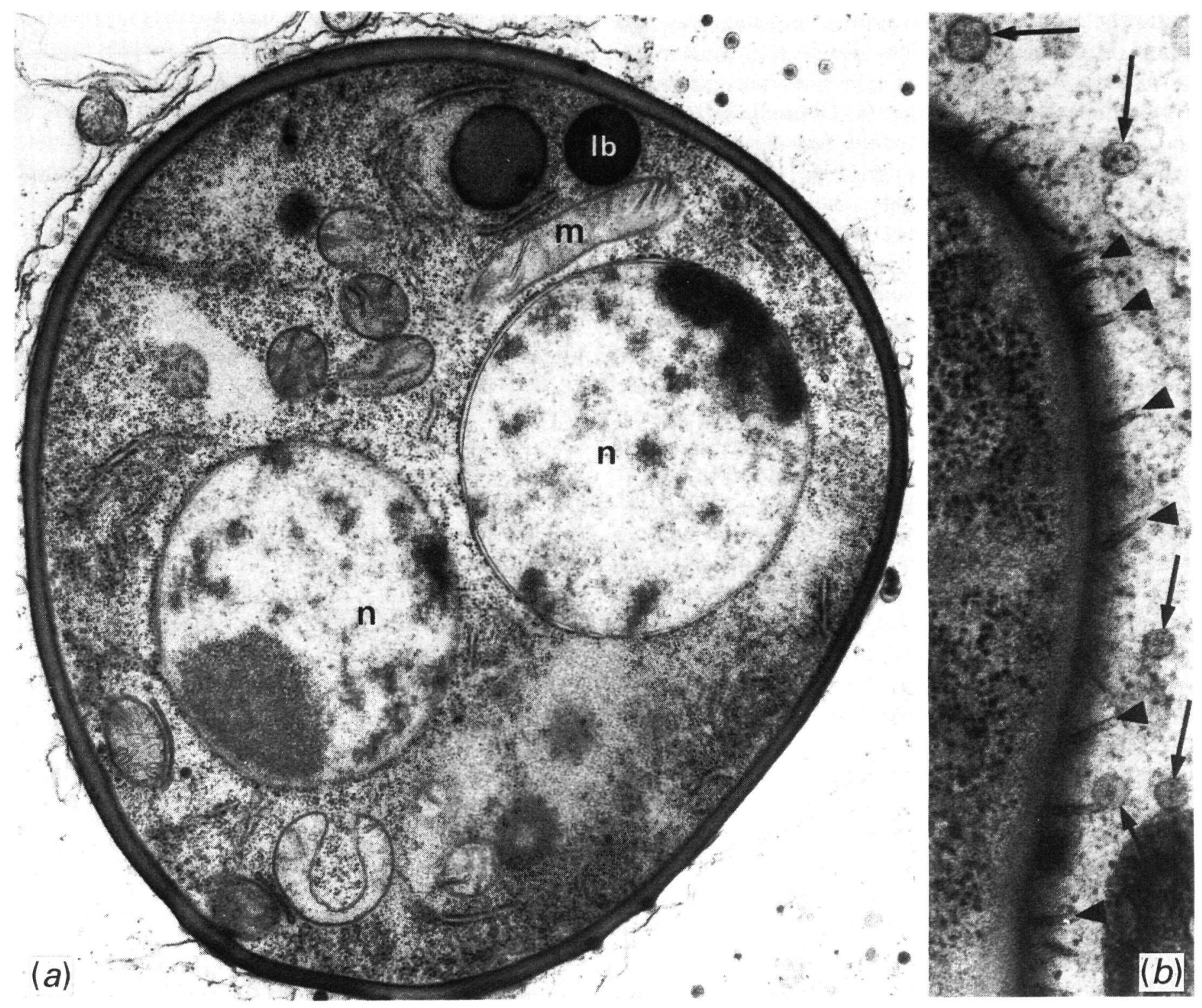

Figure 4. Infection vesicle of Colletotrichum lindemuthianum within the host cell, $24 \mathrm{~h}$ after inoculation, high pressure frozen and freeze substituted with $4 \%$ osmic acid in acetone (R. J. O'Connell and K. Mendgen, unpublished results). (a) In the infection vesicle, two nuclei ( $\mathrm{n}$ ), mitochondria (m), lipid bodies (lb) and endoplasmic reticulum are visible. The invaginated host plasma membrane smoothly surrounds the vesicle $(\times 24000)$. (b) In a grazing section, microtubules (arrowheads) and vesicles (arrows) can be seen surrounding the infection vesicle $(\times 69000)$.

of germ tube and appressorium, that of the infection hypha has only a single layer which binds both WGA and ConA. A clear refractile zone within the membrane, surrounding the infection hypha but not the penetration hypha, may result from degradation of cellulose in the membrane by enzymes secreted from the infection hypha (Bourett \& Howard, 1990; Howard et al., 1991 a).

The infection hypha of the hemibiotroph, $C$. lindemuthianum, consists of an intracellular vesicle and primary hypha. It invaginates the plasma membrane of the infected cell (Fig. 4). The intracellular biotrophic phase involves 10 to 15 epidermal and cortical cells and lasts for a few days (O'Connell et al., 1985). The germ tube (2-2.5 $\mu \mathrm{m}$ in diameter) is quite different from the infection vesicle (6-9 $\mu \mathrm{m}$ in diameter) (O'Connell, personal communication). In contrast to the fibrillar extracellular matrix around the germ tube, vesicle and primary hypha are surrounded by an amorphous matrix. Compared to the walls of the germ tubes, those of vesicle and primary hypha have low affinity to WGA during the early stages of infection. The affinity to this lectin increases as the wall of the vesicle matures (O'Connell \& Ride, 1990). The matrix around the vesicle and primary hypha is produced by both partners, the fungus and the host. This assumption is supported by the immunological detection of fungal products in the matrix and by the observation of uncoated and coated vesicles produced by the host cell around the matrix (Fig. 4) (O'Connell et al., 1985, 1986; O'Connell, 1987). The vesicle, with its matrix, is surrounded by the host plasma membrane, and host microtubules evenly enmesh the fungal structures (Fig. $4 b$ ). Infection hyphae produced on Formvar membranes bound to ConA, PWM, WGA and Bandeiraea simplicifolia agglutinin I (BSA I). However, since these structures differed morpho- 
logically from infection hyphae produced in the plant, they may also have differed in wall composition and it is not clear whether they resembled functional infection hyphae (O'Connell, 1991).

C. gloeosporioides, C. trifolii and C. graminicola, which have no biotrophic phase, produce very similar infection structures (Bailey et al., 1992). Instead of a matrix layer around vesicle and primary hypha, there is a fibrillar coat (Politis \& Wheeler, 1973; Brown, 1977; Mould et al., 1991a). The absence of a biotrophic phase may result from, or even cause, the absence of the matrix layer (O’Connell et al., 1985).

After penetration through the stomatal pore, the dikaryotic stage of rust fungi generally produces a more or less globose vesicle that elongates or bifurcates to form the infection hypha(e). The outer matrix of uredospore-derived infection hyphae binds to numerous lectins in a pattern typical of each rust fungus (Mendgen et al., 1985; Freytag \& Mendgen, 1991a). P. pachyrhizi penetrates epidermal cells directly and produces an extremely long penetration hypha that stretches through the epidermis and then forms a primary hypha (= infection hypha) (Koch et al., 1983). In this latter case, the infection hypha does not form a vesicle.

The inner wall layer of infection hyphae of $P$. pachyrhizi, $U$. viciae-fabae and $P$. graminis has high affinity to WGA (Ebrahim-Nesbat et al., 1985; Harder et al., 1986; Freytag \& Mendgen, 1991 b). Cross sections through the infection hypha of $P$. arachidis indicate that this inner wall layer is covered with additional, easily discernible coatings (Mims et al., 1989). In U. viciae-fabae, these layers were gradually dismantled by enzymatic digestion or treatment with alkali. An enzyme mixture with $\alpha$ and $\beta-1,3$-glucanase and chitinase activity dissolved walls of germ tubes and appressoria, but not those of penetration hyphae and vesicles with infection hyphae. These enzymes, and also protease, removed the outer layer(s) of the infection hypha. The remaining wall material had high affinity to ConA and LCA (Freytag, 1990; Freytag \& Mendgen, $1991 \mathrm{~b}$ ). These results suggest that mannoproteins may cover the chitin and make the wall resistant to further attack by chitinases and $\beta$-1,3-glucanases occurring in the leaf apoplast (Boller \& Métraux, 1988; Fink, Liefland \& Mendgen, 1988, 1990; Sock, Rohringer \& Kang, 1990). Undifferentiated hyphae of many filamentous fungi growing on agar are dissolved by chitinases and glucanases, especially at their tip (Collinge et al., 1993).

In monokaryotic infections, basidiospores of rust fungi produce a short germ tube, a modestly developed appressorium and a penetration hypha, which elongates to form an intraepidermal vesicle with a primary hypha ( = infection hypha) (Gold \& Mendgen, 1984). The wall of this infection hypha is quite thin and covered with a matrix. In $U$. viciae- fabae, it exhibited affinity to ConA, LCA and Ricinus communis (RCA I) lectin, a probe for D-galactose. In contrast to the germ tube, it had much less affinity to WGA, indicating that less chitin is exposed on its surface (Gold \& Mendgen, 1984, 1991; Freytag \& Mendgen, $1991 b$ ).

Comparison of the binding of nine different lectins to the dikaryotic infection hyphae and the monokaryotic infection infection hypha (= intraepidermal vesicles) of the autoecious rust $U$. viciae-fabae and the heteroecious rust $U$. rumicis suggests that lectin binding patterns correlate with the nuclear condition of the rust fungus. The monokaryotic infection hyphae from two different rusts had more similarities than the monokaryotic and the dikaryotic infection hyphae of $U$. viciae-fabae. However, a small difference in the heteroecious rust was associated with the change of host plant. Monokaryotic and dikaryotic infection hyphae of $U$. rumicis had different affinities for BSA II and LTA (Freytag, 1990; Freytag \& Mendgen, 1991 $a$ ), suggesting that $N$ acetylglucosamine and $\alpha$-L-fucose might be involved in the regulation of host compatibility. However, it should be kept in mind that the requirement for a change of host plant in heteroecious rusts is not a stable quality. $P$. graminis f. sp. tritici can, especially after a few matings, fulfil its whole life-cycle on a single host plant (Gäumann, 1959).

\section{Cytoplasmic specialization}

After the penetration of the leaf cuticle or after infection through the stomatal pore, a plant pathogenic fungus gains access to host nutrients. Such a change in supply would be expected to alter the physiology of the fungus and, as a consequence, the organization of its cytoplasm. However, there are no quantitative data available which report changes of cytoplasmic organelles during infection.

In urediosporelings of $U$. vignae, apical vesicles of the infection hypha have denser contents than similar vesicles in the germ tube (Littlefield \& Heath, 1979). Nuclear divisions occur in the substomal vesicle and, generally, eight nuclei can be found (Heath \& Heath, 1976, 1978; Chong et al., 1992; M. Stark-Umau unpublished results). Lipid droplets and microbodies, probably with glyoxysomal functions, which are quite numerous in germ tubes, decrease in number in the vesicle and in the infection hypha (Mendgen, $1973 b$; Littlefield \& Heath, 1979). This observation could reflect a switch from lipid metabolism in the germ tube to host carbohydrate-dependent metabolism as soon as the fungus grows within the intercellular space or produces haustoria in the host cell.

The endoplasmic reticulum appears more differentiated during growth within the host plant. In germ tubes of $U$. appendiculates, strands of ER are generally not very complex (Hoch \& Staples, 1983). 
In intercellular hyphae, and in haustoria, the ER formed tubular vesicular complexes (tvc 1) (Welter, Müller \& Mendgen, 1988).

Infections starting from basidiospores of $U$. vignae induce hypersensitive cell death as soon as they penetrate epidermal cells of an incompatible host plant (Heath, 1989). Aqueous exudates from differentiated, but not from undifferentiated germlings, exhibited a similar cultivar-specific elicitation of cell necrosis (Chen \& Heath, 1992). This experiment suggests that the elicitor of cell necrosis is produced by the fungus only during the differentiation of structures that are correlated with penetration and colonization of the leaf cell.

\section{Enzyme production during differentiation of infection hypha}

The only investigations dealing with the production of cell wall-degrading enzymes in relation to differentiation of infection structures have been carried out with Colletotrichum spp. (Suzuki et al., 1982, 1983; Katoh et al., 1988; Wijesundera et al., 1989) and with $U$. viciae-fabae (Deising \& Mendgen, 1992; Frittrang, Deising \& Mendgen, 1992; Heiler et al., 1993).

Wijesundera et al. (1989) presented evidence that pectin lyase activity is expressed at certain stages of development of $C$. lindemuthianum and that formation of the enzyme may be correlated with the switch from biotrophic growth to destructive necrotrophic growth. Pectin lyase activity was detected in extracts of infected $P$. vulgaris tissue starting from $4 \mathrm{~d}$ after inoculation. Infection hyphae began to develop at that stage of fungal development. Enzyme activity was not much altered up to $6 \mathrm{~d}$ after inoculation, i.e. when infection hyphae were found in up to 15 host cells. This stage of disease development is indicated by the appearance of brown flecks (small groups of necrotic cells). As soon as secondary hyphae develop, enormous increases in pectin lyase activity are found, and large-scale death of plant cells and tissue collapse are observed (Wijesundera et al., 1989). Cell death is likely to be due to toxicity of the lyase per se, or to hypersensitive cell death in response to pectin or polygalacturonate fragments produced by the enzyme(s) (Cervone et al., 1987, 1989; Wijesundera et al., 1989; Benhamou et al., 1991; Mathieu et al., 1991). Interestingly, though produced in vitro on media containing pectic substances or isolated hypocotyl cell walls, endo-polygalacturonase was not detectable in vivo during biotrophic or necrotrophic disease development (Wijesundera et al., 1989). This may be due to the presence in bean $(P$. vulgaris) cell walls of an inhibitor of this hydrolase (Cervone et al., 1981; Lafitte et al., 1984; Toubart et al., 1992). Biochemical studies have been confirmed by cytochemical experiments, in which endo-polygalacturonase was labelled by gold-conjugated polygalacturonase-inhibiting protein, and pectin degradation was detected by probing with Aplysia gonad lectin (Benhamou et al., 1991).

In the biotrophic fungus $U$. viciae-fabae, pectin esterase isoenzymes have been separated by chromatofocusing (Frittrang et al., 1992), and three forms of this enzyme, showing pIs of $8 \cdot 4,5 \cdot 7$, and 4.7 , were detected $9 \mathrm{~h}$ after inoculation, i.e. when young infection hyphae (substomatal vesicles) are formed (Fig. $3 b$ ). The predominating form (pectinesterase A) increases to yield maximal activity at 20-24 h p.i., whereas form B increases until $12 \mathrm{~h}$ p.i. and remains more or less constant at this level of activity (H. Deising, A. K. Frittrang and K. Mendgen, unpublished results). In contrast to forms $\mathrm{A}$ and $\mathrm{B}$, which contribute 78 and $20 \%$ of the total pectinesterase activity, respectively, isoform $\mathrm{C}$ represents only c. $2 \%$ (Frittrang et al., 1992). At the stage of infection hypha differentiation, activity of neutral cellulases increases dramatically, and this increase continues until haustorial mother cell formation (Heiler et al., 1993). These neutral cellulases, consisting of three isoforms of isoelectric points of $7 \cdot 3,7 \cdot 1$, and $6 \cdot 4$, increase from $3 \%$ of the total activity at $7 \mathrm{hp} . \mathrm{i}$. to $37 \%$ at $18 \mathrm{~h} \mathrm{p.i.,} \mathrm{and} 45 \%$ when haustorial mother cells were formed ( $24 \mathrm{~h}$ p.i.). It is important to note that both cellulases and pectin esterases are not substrate-inducible, but strictly developmentally controlled (Frittrang et al., 1992; Heiler et al., 1993; H. Deising, A. K. Frittrang and K. Mendgen, unpublished results). In addition, neither enzyme is repressed by mono- and disaccharides such as glucose, fructose, and sucrose.

Polygalacturonate lyase, in contrast, is regulated by both the substrate polygalacturonate and the developmental stage of the rust fungus. While in the absence of substrate no enzyme activity is detectable, polygalacturonate lyase activity is formed beginning at $14 \mathrm{~h}$ p.i. on artificial membranes when polygalacturonate is applied to the dormant spores. At this time significant numbers of infection structures begin to differentiate haustorial mother cells, and the activity increases up to $24 \mathrm{~h}$ p.i. (Fig. $3 c$ ). If substrate is given when substomatal vesicles are differentiated, i.e. when the fungus normally contacts the pectinaceous layer of the plant cell wall, the kinetics of enzyme production are identical to those when polygalacturonate is directly applied to the spores. If substrate is given to infection structures differentiated for $18 \mathrm{~h}$, significant polygalacturonate lyase activity is detectable $6 \mathrm{~h}$ later. These results clearly demonstrate that expression of polygalacturonate lyase activity requires both differentiation of infection structures, probably haustorial mother cells, and the presence of substrate (Deising \& Mendgen, 1992). The enzyme has an extremely high isoelectric point $(>10 \cdot 5)$ and $\mathrm{pH}$ optimum $(10 \cdot 3)$, shows an absolute requirement for $\mathrm{Ca}^{2+}$, exhibits decreasing activity with increasing degree of methylation of the 
polygalacturonate chain, and is thus clearly characterized as a polygalacturonate lyase (H. Deising, unpublished results).

The physico-chemical properties of the cell walldegrading enzymes of $U$. viciae-fabae may be of critical importance in avoiding extended tissue damage and thus for establishment of biotrophy. Since the $\mathrm{pH}$ of the apoplast is in the weakly acidic range ( $\mathrm{pH} 5 \cdot 0-6 \cdot 5)$ (Grignon \& Sentenac, 1991), the potentially destructive polygalacturonate lyase ( $\mathrm{pI}>10 \cdot 5)$, the predominant pectin-esterase form A (pI 8.4), and to a certain extent the neutral cellulases (pI $7 \cdot 1$ and $7 \cdot 3$ ), are thought to be positively charged and tightly bound to the negatively charged sites of the plant cell wall. Their activity would thus be restricted to the site of secretion. Electron microscopy has shown that dissolution of cell walls by rust fungi is restricted to the site of penetration (Chong et al., 1981; Taylor \& Mims, 1991) and thus supports this concept.

\section{FUTURE PROSPECTS}

In the past, research on fungal plant pathogens has focussed separately on microscopical analyses of fungal structures or on molecular or biochemical analyses of genes or gene products which might be important in pathogenesis. During the last few years, however, a few fungal systems, such as Magnaporthe, Colletotrichum, and Uromyces, have been studied by both microscopical and biochemical techniques. Combining such results, e.g. the localization of gene products with the electron microscope at the site of interaction or even at the site of penetration, will considerably improve the understanding of hostparasite interactions. Such studies may explain ambiguous results obtained by molecular, biochemical or microscopical techniques used alone.

\section{ACKNOWLEDGEMENTS}

We are indebted to Dr R. J. Howard (DuPont, Wilmington, DE) and Dr R. J. O'Connell (University of Bristol, UK) for critically reading the manuscript and for donation of the sketches of Magnaporthe and Colletotrichum infection structures. We also thank Dr M. Hahn, S. Heiler and M. Haug for helpful discussions throughout the work, and the Deutsche Forschungsgemeinschaft for grants (Me 523).

\section{REFERENCES}

Aist JR, Bushnell WR. 1991. Invasion of plants by powdery mildew fungi, and cellular mechanisms of resistance. In: Cole GT, Hoch HC, eds. The fungal spore and disease initiation in plants and animals. New York: Plenum Press, 321-345.

Allen EA, Hoch HC, Steadman JR, Stavely RJ. 1991. Influence of leaf surface features on spore deposition and the epiphytic growth of phytopathogenic fungi. In: Andrews JH, Hirano SS, eds. Microbial ecology of leaves. New York: Springer Verlag, $87-110$

Bailey JA, O'Connell RJ, Pring RJ, Nash C. 1992. Infection strategies of Colletotrichum species. In: Bailey JA, Jeger MJ, eds. Colletotrichum: Biology, pathology and control. Oxon: Commonwealth Agricultural Bureau International, 88-120.

Bartnicki-Garcia S, Hergert F. \& Gierz G. 1989. Computer simulation of fungal morphogenesis and the mathematical basis for hyphal (tip) growth. Protoplasma 153: 46-57.

Beckett A, Tatnell JA, Taylor N. 1990. Adhesion and preinvasion behaviour of urediniospores of Uromyces viciae-fabae during germination on host and synthetic surfaces. Mycological Research 94: 865-875.

Benhamou N, Lafitte C, Barthe J-P, Esquerré-Tugayé M-T. 1991. Cell surface interactions between bean leaf cells and Colletotrichum lindemuthianum. Cytochemical aspects of pectin breakdown and fungal endopolygalacturonase accumulation. Plant Physiology 97: 234-244.

Bergstrom GC, Nicholson RL. 1981. Invertase in the spore matrix of Colletotrichum graminicola. Phytopathologische Zeitschrift 102: 139-147.

Blaich R, Heintz C, Wind R. 1989. Studies on conidial germination and initial growth of the grapevine powdery mildew Uncinula necator on artificial substrates. Applied Microbiology and Biotechnology 30: 415-421.

Boller T, Métraux JP. 1988. Extracellular localization of chitinase in cucumber. Physiological and Molecular Plant Pathology 33: 11-16.

Bonfante-Fasolo P, Perotto S. 1992. Plants and endomycorrhizal fungi: The cellular and molecular basis of their interaction. In: Verma DPS, ed. Molecular signals in plant-microbe communications. Boca Raton: CRC Press, 445-470.

Bonnen AM, Hammerschmidt R. 1989. Role of cutinolytic enzymes in infection of cucumber by Colletotrichum lagenarium. Physiological and Molecular Plant Pathology 35 : 475-481.

Bourett TM, Howard RJ. 1990. In vitro development of penetration structures in the rice blast fungus Magnaporthe grisea. Canadian Fournal of Botany 68: 329-342.

Bourett TM, Howard RJ. 1991. Ultrastructural immunolocalization of actin in a fungus. Protoplasma 163: 199-202.

Bourett TM, Howard RJ. 1992. Actin in penetration pegs of the fungal rice blast pathogen, Magnaporthe grisea. Protoplasma 168: 20-26.

Brown GE. 1977. Ultrastructure of penetration of ethylenedegreened Robinson tangerines by Colletotrichum gloeosporioides. Phytopathology 67: 315-320.

Brown W, Harvey CC. 1927. On the entrance of parasitic fungi in the host plant. Annals of Botany 41 : 643-662.

Büsgen M. 1893. Ueber einige Eigenschaften der Keimlinge parasitischer Pilze. Botanische Zeitung 51: 53-70.

Bushnell WR. 1984. Structural and Physiological Alterations in Susceptible Host Tissue. In : Bushnell WR, Roelfs AP, eds. The cereal rusts. Orlando: Academic Press, 477-507.

Carver TLW, Ingerson SM. 1987. Responses of Erysiphe graminis germlings to contact with artifical and host surfaces. Physiological and Molecular Plant Pathology 30: 359-372.

Cervone F, Andebrhan T, Coutts RHA, Wood RKS. 1981. Effect of French Bean tissue and leaf protoplasts on Colletotrichum lindemuthianum polygalacturonase. Phytopathologische Zeitschrift 102: 238-246.

Cervone F, De Lorenzo G, Degrà L, Salvi G. 1987. Elicitation of necrosis in Vigna unguiculata Walp. by homogeneous Aspergillus niger endo-polygalacturonase and by $\alpha$-D-galacturonate oligomers. Plant Physiology 85 : 626-630.

Cervone H, De Lorenzo G, D'Ovidio R, Hahn MG, Ito Y, Darville A, Albersheim P. 1989. Phytotoxic effects and phytoalexin-elicitor activity of microbial pectic enzymes. In: Graniti Aea, ed. Phytotoxins and plant pathogenesis. Berlin, Heidelberg: Springer Verlag, 473-477.

Chapela JH, Petrini O, Hagmann L. 1991. Monolignol glucosides as specific recognition messengers in fungus-plant symbioses. Physiological and Molecular Plant Pathology 39: 289-298.

Chaubal R, Wilmot VA, Wynn WK. 1991. Visualization, adhesiveness, and cytochemistry of the extracellular matrix produced by urediniospore germ tubes of Puccinia sorghi. Canadian Fournal of Botany 69: 2044-2054.

Chen C-Y, Heath MC. 1992. Effect of stage of development of the cowpea rust fungus on the release of a cultivar-specific elicitor of necrosis. Physiological and Molecular Plant Pathology 40: $23-30$. 
Cheong J-J, Hahn M. 1991. A specific high-affinity binding site for the hepta- $\beta$-glucoside elicitor exists in soybean membranes. The Plant Cell 3: 137-147.

Chong J, Harder DE, Rohringer R. 1981. Ontogeny or monoand dikaryotic rust haustoria: cytochemical and ultrastructural studies. Phytopathology 71: 975-983.

Chong J, Harder DE, Rohringer R. 1985. Cytochemical studies on Puccinia graminis f. sp. tritici in a compatible wheat host. I. Walls of intercellular hyphal cells and haustorium mother cells. Canadian Fournal of Botany 63: 1713-1724.

Chong J, Kang Z, Kim WK, Rohringer R. 1992. Multinucleate condition of Puccicnia striiformis in colonies isolated from infected wheat leaves with macerating enzymes. Canadian Fournal of Botany 70: 222-224.

Chumley FG, Valent B. 1990. Genetic analysis of melanindeficient, nonpathogenic mutants of Magnaporthe grisea. Molecular Plant-Microbe Interactions 3: 135-143.

Collinge DL, Kragh KM, Mikkelsen JD, Nielsen KK, Rasmussen U, Vad K. 1993. Plant chitinases. The Plant fournal 3: 31-40.

Collmer A, Keen NT. 1986. The role of pectic enzymes in plant pathogenesis. Annual Review of Phytopathology 24: 383-409.

Cooper RM. 1983. The mechanism and significance of enzymic degradation of host cell walls by parasites. In: Callow JA, ed. Biochemical plant pathology. John Wiley \& Sons Ltd, 101-135.

Cooper RM. 1984. The role of cell wall-degrading enzymes in infection and damage. In: Wood RKS, Jellis GJ, eds. Plant diseases : infection, damage and loss. Oxford: Blackwell Scientific Publications, 13-27.

Cooper RM, Durrands RK. 1989. Selection, characterization, pathogenicity and virulence of pectinase-deficient mutants of Verticillium albo-atrum. In: Tjamos EC, Beckman C, eds. Vascular wilt diseases of plants. Berlin, Heidelberg: Springer Verlag, 325-335.

Corlett M, Chong J. 1977. Ultrastructure of the appressorium of Spilocaea pomi. Canadian Fournal of Botany 55: 5-7.

Cosio EG, Frey T, Verduyn R, van Boom J, Ebel J. 1990. Highaffinity binding of a synthetic heptaglycoside and fungal glycan phytoalexin elicitors to soybean membranes. FEBS Letters 271 : 223-226.

Coughlan MP, Ljungdah1 LG. 1988. Comparative biochemistry of fungal and bacterial cellulolytic enzyme systems. In: Aubert $\mathrm{J}-\mathrm{P}$, Beguin P, Millet J, eds. Biochemistry and genetics of cellulose degradation. London, San Diego, New York, Boston, Sydney, Tokyo, Toronto: Academic Press-Harcourt Brace Jovanovich, 11-30.

Crawford MS, Kolattukudy PE. 1987. Pectate lyase from Fusarium solani $\mathrm{f}$. sp. pisi : purification, characterization, in vitro translation of the mRNA, and involvement in pathogenicity. Archives of Biochemistry and Biophysics 258: 196-205.

Davies ME, Butler GM. 1986. Development of infection structures of the rust Puccinia porri on leek leaves. Transactions of the British Mycological Society 86: 475-515.

DeBary A. 1884. Vergleichende Morphologie und Biologie der Pilze, Mycetozoen und Bacterien. Leipzig: Engelmann.

Deising H, Jungblut PR, Mendgen K. 1991. Differentiationrelated proteins of the broad bean rust fungus Uromyces viciaefabae, as revealed by high resolution two-dimensional polyacrylamide gel electrophoresis. Archives of Microbiology 155: 191-198.

Deising H, Mendgen K. 1992. Developmental control of enzyme production and cell wall modification in rust fungi, and defence reactions of the host plant. In: U, T, Stahl P, eds. Molecular biology of filamentous fungi. Weinheim, New York, Basel, Cambridge: VCH Verlagsgesellschaft mbH, 27-44.

Deising $H$, Nicholson RL, Haug M, Howard RJ, Mendgen K. 1992. Adhesion pad formation and the involvement of cutinase and esterases in the attachment of urediniospores to the host cuticle. The Plant Cell 4: 1101-1111

Dickinson S. 1949. Studies in the physiology of obligate parasitism. II. The behaviour of the germ tubes of certain rusts in contact with various membranes. Annals of Botany 13 : 219-236.

Dickman MB, Patil SS, Kolattukudy PE. 1983. Effects of organophosphorous pesticides on cutinase activity and infection of papayas by Colletotrichum gloeosporioides. Phytopathology 73 : 1209-1214.

Dickman MB, Podila GK, Kolattukudy PE. 1989. Insertion of cutinase gene into a wound pathogen enables it to infect intact host. Nature 342: 446-448.

Dickman MD, Patil SS, Kolattukudy PE. 1982. Purification, characterization and role in infection of an extracellular cutinolytic enzyme from Colletotrichum gloeosporioides Penz. on Carica papaya L. Physiological Plant Pathology 20 : 333-347.

Ebrahim-Nesbat F, Hoppe HH, Rohringer R. 1985. Lectin binding studies on the cell walls of soybean rust (Phakopsora pachyrhizi Syd.). Phytopathologische Zeitschrift 114: 97-107.

Fink W, Liefland M, Mendgen K. 1988. Chitinases and $\beta-1,3-$ glucanases in the apoplastic compartment of oat leaves (Avena sativa L.). 1. Plant Physiology 88: 270-275.

Fink W, Liefland M, Mendgen K. 1990. Comparison of various stress responses in oat in compatible and nonhost resistant interactions with rust fungi. Physiological and Molecular Plant Pathology 37: 309-321

Förster H, Mendgen K. 1987. Immunocytochemical localization of pectinesterases in hyphae of Phytophthora infestans. Canadian Fournal of Botany 65 : 2607-2613.

Förster H, Rashed I. 1985. Purification and characterization of extracellular pectinesterases from Phytophthora infestans. Plant Physiology 77: 109-112.

Freytag S. 1990. Oberflächenkohlenhydrate und Zellwandaufbau von in vitro-induzierten Infektionsstrukturen von Rostarten. Dissertation, Konstanz.

Freytag S, Bruscaglioni L, Gold RE, Mendgen K. 1988. Basidiospores of rust fungi (Uromyces species) differentiate infection structures in vitro. Experimental Mycology 12: 275-283.

Freytag S, Mendgen K. $1991 \boldsymbol{a}$. Carbohydrates on the surface of urediniospore- and basidiospore-derived infection structures of heteroecious and autoecious rust fungi. New Phytologist 119: $527-534$

Freytag S, Mendgen K. 1991 b. Surface carbohydrates and cell wall structure of in vitro induced uredospore infection structures of Uromyces viciae-fabae before and after treatment with enzymes and alkali. Protoplasma 161: 94-103.

Frittrang AK, Deising H, Mendgen K. 1992. Characterization and partial purification of pectinesterase, a differentiationspecific enzyme of Uromyces viciae-fabae. Fournal of General Microbiology 138: 2213-2218.

Fuchs WH. 1976. History of Physiological Plant Pathology. In: Heitefuss R, Williams PH, eds. Physiological Plant Pathology. Berlin: Springer Verlag, 1-26.

Gäumann E. 1951. Pflanzliche Infektionslehre. Basel: Birkhäuser. Gäumann E. 1959. Die Rostpilze Mitteleuropas. Bern: Bücheler $\&$ Co.

Gold RE, Mendgen K. 1984. Cytology of basidiospore germination, penetration, and early colonization of Phaseolus vulgaris by Uromyces appendiculatus var. appendiculatus. Canadian Fournal of Botany 62: 1989-2002.

Gold RE, Mendgen K. 1991. Rust basidiospore germlings and disease initiation. In: Cole GT, Hoch $\mathrm{HC}$, eds. The fungal spore and disease initiation in plants and animals. New York: Plenum Publ. Corp.

Grambow, J-J. 1977. The influence of volatile leaf constitutents on the in vitro differentiation and growth of Puccinia graminis $\mathrm{f}$. sp. tritici. Zeitschrift für Pflanzenphysiologie 85 : 361-372.

Grignon C, Sentenac H. 1991. $\mathrm{pH}$ and ionic conditions in the apoplast. Annual Review of Plant Physiology and Plant Molecular Biology 42: 103-128.

Hajlaoui MR, Benhamou N, Bélanger RR. 1992. Cytochemical study of the antagonistic activity of Sporothrix flocculosa on rose powdery mildew, Sphaerotheca pannosa var rosae. Phytopathology 82: 583-589.

Hamer JE, Howard RJ, Chumley FG, Valent B. 1988. A mechanism for surface attachment in spores of a plant pathogenic fungus. Science 239: 288-290.

Harder DE, Chong J. 1991. Rust Haustoria. In: Mendgen K Lesemann D-E, eds. Electron microscopy of plant pathogens. Berlin: Springer Verlag, 235-250.

Harder DE, Chong J, Rohringer R, Kim WK. 1986. Structure and cytochemistry of the walls of urediospores, germ tubes, and appressoria of Puccinia graminis tritici. Canadian Fournal of Botany 64: 476-485.

Hardham AR. 1992. Cell biology of pathogenesis. Annual Review of Plant Physiology and Plant Molecular Biology 43 . 491-526. 
Heath IB. 1987. Preservation of a labile cortical array of actin filaments in growing hyphal tips of the fungus Saprolegnia ferax. European Fournal of Cell Biology 44: 10-16.

Heath IB. $1990 \boldsymbol{\alpha}$. The roles of actin in tip growth of fungi. International Review of Cytology 123: 95-127.

Heath IB. 1990 b. Tip growth in plant and fungal cells. San Diego: Academic Press.

Heath IB, Heath MC. 1976. Ultrastructure of mitosis in the cowpea rust fungus Uromyces phaseoli var. vignae. The fournal of Cell Biology 70: 592-607.

Heath MC. 1989. In vitro formation of haustoria of the cowpea rust fungus, Uromyces vignae, in the absence of a living plant cell. I. Light microscopy. Physiological and Molecular Plant Pathology 35: 357-366.

Heath MC. 1990. In vitro formation of haustoria of the cowpea rust fungus Uromyces vignae in the absence of a living plant cell. II. Electron microscopy. Canadian Fournal of Botany 68 : 278-287

Heath MC, Heath IB. 1975. Ultrastructural changes associated with the haustorial mother cell septum during haustorium formation in Uromyces phaseoli var. vignae. Protoplasma 84: 297-314

Heath MC, Heath IB. 1978. Structural studies of the development of infection structures of cowpea rust, Uromyces phaseoli var. vignae. I. Nucleoli and nuclei. Canadian Fournal of Botany 56: 648-661.

Heath MC, Howard RJ, Valent B, Chumley FG. 1992. Ultrastructural interactions of one strain of Magnaporthe grisea with goosegrass and weeping lovegrass. Canadian Fournal of Botany 70: 779-787.

Heath MC, Perumalla CJ. 1988. Haustorial mother cell development by Uromyces vignae on collodium membranes. Canadian Fournal of Botany 66: 736-741

Heath MC, Valent B, Howard RJ, Chumley FG. 1990. Correlations between cytologically detected plant-fungal interactions and pathogenicity of Magnaporthe grisea toward weeping lovegrass. Phytopathology 80: 1382-1386.

Heiler S, Mendgen K, Deising H. 1993. Cellulolytic enzymes of the obligately biotrophic rust fungus Uromyces viciae-fabae are regulated differentiation-specifically. Mycological Research (in the press).

Hickman MJ, Epstein L. 1988. Nectria haematococca macroconidia attach to plant surfaces. Phytopathology 78: 1523 (Abstr.).

Hoch HC. 1977. Use of permanganate to increase electron opacity of fungal walls. Mycologia 6: 1209-1213.

Hoch HC. 1991. Preservation of cell ultrastructure by freezesubstitution. In: Mendgen K, Lesemann D-E, eds. Electron microscopy of plant pathogens. Berlin: Springer Verlag, 1-16.

Hoch HC, Staples RC. 1983. Ultrastructural organization of the non-differentiated uredospore germling of Uromyces phaseoli variety typica. Mycologia 75 : 795-824.

Hoch HC, Staples RC. 1984. Evidence that cyclic AMP initiates nuclear division and infection structure formation in the bean rust fungus, Uromyces phaseoli. Experimental Physiology 8: 37- 46 .

Hoch HC, Staples RC. 1987. Structural and chemical changes among the rust fungi during appressorium development. Annual Reviews of Phytopathology 25: 231-247.

Hoch HC, Staples RC. 1991. Signaling for infection structure formation in fungi. In: Cole GT, Hoch $\mathrm{HC}$, eds. The fungal spore and disease initiation in plants and animals. New York: Plenum Press, 25-46.

Hoch HC, Staples RC, Bourett TM. 1987 a. Chemically induced appressoria in Uromyces appendiculatus are formed aerially, apart from the substrate. Mycologia 79: 418-424.

Hoch HC, Staples RC, Whitehead B, Comeau J, Wolf ED. $1987 \mathrm{~b}$. Signaling for growth orientation and cell differentiation by surface topography in Uromyces. Science 235: 1659-1662.

Hohl HR. 1991. Surface-related host-pathogen interactions in Phytophthora. In: Lucas JA, Shattock RC, Shaw DS, Cooke IR, eds. Phytophthora. Cambridge: Cambridge University Press, 70-89.

Hohl HR. 1992. Cytology and morphogenesis of fungal cells. In : Behnke HD, Esser K, Kubitzki K, Runge M, Ziegler H, eds. Progress in botany. Berlin, Heidelberg: Springer Verlag, 1-28.

Hohl HR, Balsiger S. 1986. Probing the surfaces of soybean protoplasts and of germ tubes of the soybean pathogen
Phytophthora megasperma f. sp. glycinea with lectins. Botanica Helvetica 98 : 289-297.

Holden DW, Strange RN. 1985. Biochemical characteristics of sporelings of Puccinia graminis f. sp. tritici and protoplasts from wheat isolines of potential significance in specificity. Plant Pathology 33: 233-243.

Hoppe H-H, Koch E. 1989. Defense reactions in host and nonhost plants against the soybean rust fungus (Phakopsora pachyrhizi Syd.). Fournal of Phytopathology 125: 77-88.

Howard RJ, Bourett TM, Ferrari MA. 1991a. Infection by Magnaporthe: an in vitro analysis. In: Mendgen K, Lesemann D-E, eds. Electron microscopy of plant pathogens. Berlin: Springer Verlag, 251-264.

Howard RJ, Ferrari MA. 1989. Role of melanin in appressorium function. Experimental Mycology 13: 403-418.

Howard RJ, Ferrari MA, Roach DH, Money NP. $1991 b$. Penetration of hard substrates by a fungus employing enormous turgor pressures. Proceedings of the National Academy of Sciences USA 88: 11281-11284.

Jackson SL, Heath IB. 1990. Evidence that actin reinforces the extensible hyphal apex of the oomycete Saprolegnia ferax. Protoplasma 157: 144-153.

Johnston DJ, Williamson B. 1992. Purification and characterization of four polygalacturonases from Botrytis cinerea. Mycological Research 96: 343-349.

Kaminskyj SGW, Day AW. 1984. Chemical induction of infection structures in rust fungi. II. Inorganic ions. $E x$ perimental Mycology 8: 193-201.

Kaminskyj SGW, Garrill A, Heath IB. 1992. The relation between turgor and tip growth in Saprolegnia ferax: Turgor is necessary, but not sufficient to explain apical extension rates. Experimental Mycology 16: 64-75.

Kapooria RG, Mendgen K. 1985. Infection structures and their surface changes during differentiation in Uromyces fabae. Phytopathologische Zeitschrift 113: 317-323.

Katoh M, Hirose I, Kubo Y, Hikichi Y, Kunoh H, Furusawa I, Shishiyama J. 1988. Use of mutants to indicate factors prerequisite for penetration of Colletotrichum lagenarium by appressoria. Physiological and Molecular Plant Pathology 32: $177-184$

Keon JPR, Byrde RJW, Cooper RM. 1987. Some aspects of fungal enzymes that degrade plant cell walls. In: Pegg GF, Ayres PG, eds. Fungal infection of plants. Symposium of the British Mycological Society. Cambridge, New York, New Rochelle, Melbourne, Sydney: Cambridge University Press, $133-157$

Kim HB, Haarer BK, Pringle JR. 1991. Cellular morphogenesis in the Saccharomyces cerevisiae cell cycle: localization of the CDC3 gene product and the timing of events at the budding site. The Fournal of Cell Biology 112: 535-544.

Koch E, Ebrahim-Nesbat F, Hoppe HH. 1983. Light and electron microscopic studies on the development of soybean rust (Phakopsora pachyrhizi Syd.) in susceptible soybean leaves. Phytopathologische Zeitschrift 106: 302-320.

Koch E, Hoppe H-H. 1988. Development of infection structures by the direct-penetrating soybean rust fungus (Phakopsora pachyrhizi Syd.) on artificial membranes. Fournal of Phytopathology 122: 232-244.

Kolattukudy PE. 1985. Enzymatic penetration of the plant cuticle by fungal pathogens. Annual Review of Phytopathology 23: $223-250$.

Kolattukudy PE, Crawford MS. 1987. The role of polymer degrading enzymes in fungal pathogenesis. In: Nishimura S, Vance VP, Doke N, eds. Molecular determinants of plant diseases. Tokyo, Berlin, Heidelberg, New York, London, Paris: Japan Scientific Society Press and Springer Verlag, 75-95.

Kolattukudy PE, Podila GK, Roberts E, Dickman MD. 1989. Gene expression resulting from the early signals in plantfungus interaction. In : Liss AR, ed. Molecular biology of plantpathogen interactions. Columbus, Ohio: The Ohio State University, 87-102.

Kolattukudy PE, Podila GK, Sherf BA, Bajar MA, Mohan R. 1991. Mutual triggering of gene expression in plant-fungus interactions. In: Hennecke H, Verma DPS, eds. Advances in molecular genetics of plant-microbe interactions. Dordrecht, Boston, London: Kluwer Academic Publishers, 242-249.

Kolattukudy PE, Soliday CL, Woloshuk CP, Crawford M. 1985. Molecular biology of the early events in the fungal 
penetration into plants. In: Liss AR, ed. Molecular genetics of filamentous fungi. Pullman, Washington: Washington State University, 421-438.

Köller W, Allan CR, Kolattukudy PE. 1982. Role of cutinase and cell wall degrading enzymes in infection of Pisum sativum by Fusarium solani f. sp. pisi. Physiological Plant Pathology 20: 47-60.

Köller W, Parker DM. 1989. Purification and characterization of cutinase from Venturia inaequalis. Phytopathology 79: 278-283.

Köller W, Parker DM, Becker CM. 1991. Role of cutinase in the penetration of apple leaves by Venturia inaequalis. Phytopathology 81: 1375-1379.

Kubo Y, Furusawa I. 1991. Melanin Biosynthesis: Prerequisite for successful invasion of the plant host by appressoria of Colletotrichum and Pyricularia. In: Cole GT, Hoch HC, eds. The fungal spore and disease initiation in plants and animals. New York: Plenum Press, 205-218.

Kubo Y, Furusawa I, Shishiyama J. 1987. Relation between pigment intensity and penetrating ability in appressoria of Colletotrichum lagenarium. Canadian Fournal of Microbiology 33: 871-873

Kunoh H, Nicholson RL, Kobayashi I. 1991. Extracellular materials of fungal structures: Their significance at penetration stages of infection. In: Mendgen K, Lesemann D-E, eds. Electron microscopy of plant pathogens. Berlin, Heidelberg, New York: Springer Verlag, 223-234.

Kunoh H, Yamaoka N, Yoshioka H, Nicholson RL. 1988. Preparation of the infection court by Erysiphe graminis. I. Contact-mediated changes in morphology of the conidium surface. Experimental Mycology 12: 325-335

Kwon YH, Hoch HC. 1991. Temporal and spatial dynamics of appressorium formation in Uromyces appendiculatus. Experimental Mycology 15: 116-131.

Kwon YH, Hoch HC, Aist JR. 1991. Initiation of appressorium formation in Uromyces appendiculatus: Organization of the apex, and the responses involving microtubules and apical vesicles. Canadian Fournal of Botany 69: 2560-2573.

Lafitte C, Barthe JP, Montillet JL, Touzé, A. 1984. Glycoprotein inhibitors of Colletotrichum lindemuthianum endopolygalacturonase in near isogenic lines of Phaseolus vulgaris resistant and susceptible to anthracnose. Physiological Plant Pathology 25: 39-53

Landes M, Hoffmann GM. 1979. Zum Keimungs- und Infektionsverlauf bei Colletotrichum lindemuthianum auf Phaseolus vulgaris. Phytopathologische Zeitschrift 95 : 259-273.

Littlefield LJ, Heath MC. 1979. Ultrastructure of rust fungi. New York: Academic Press.

Macko V, Renwick JAA, Rissler JF. 1978. Acrolein induces differentiation of infection structures in the wheat stem rust fungus. Science 199: 442-443.

Maheswari R, Hildebrandt AC, Allen PJ. 1967. The cytology of infection structure development in uredospore germ tubes of Uromyces phaseoli var. typica (Pers.) Wint. Canadian Fournal of Botany 45: 447-450

Maiti IB, Kolattukudy PE. 1979. Prevention of fungal infection of plants by specific inhibition of cutinase. Science 205: 507-508.

Mann B. 1962. Role of pectic enzymes in the Fusarium wilt syndrome of tomato. Transactions of the British Mycological Society 45: 169-178.

Marcus L, Barash I, Sneh B, Koltin Y, Finkler A. 1986. Purification and characterization of pectolytic enzymes produced by virulent and hypovirulent isolates of Rhizoctonia solani Kuhn. Physiological and Molecular Plant Pathology 29 325-336.

Marks GC, Bergee JG, Riker AJ. 1965. Direct penetration of leaves of Populos tremuloides by Colletotrichum gleosporiodes. Phytopathology 55: 408-412.

Mathieu Y, Kurkdjian A, Xia H, Guern J, Koller A, Spiro MD, O'Neill M, Albersheim P, Darvil A. 1991. Membrane responses induced by oligogalacturonides in suspensioncultured tobacco cells. The Plant Fournal 1: 333-344.

McKeen WE, Smith R, Bhattacharya PK. 1969. Alterations of the host wall surrounding the infection peg of powdery mildew fungi. Canadian Fournal of Botany 47: 701-706.

McRae CF, Stevens GR. 1990. Role of conidial matrix of Colletotrichum orbiculare in pathogenesis of Xanthium spinosum. Mycological Research 94 : 890-896.
Mendgen K. 1973a. Feinbau der Infektionsstrukturen von Uromyces phaseoli. Phytopathologische Zeitschrift 78: 109-120.

Mendgen K. 1973b. Microbodies (glyoxysomes) in infection structures of Uromyces phaseali. Protoplasma 78: 477-482.

Mendgen K. 1982. Differential recognition of the outer and inner walls of epidermal cells by a rust fungus. Naturwissenschaften 69: $502-503$

Mendgen K. 1989. Secretion in the parasitic phase of rust fungi. In: Lugtenberg BJJ, ed. Signal molecules in plant-microbe interactions. Berlin: Springer Verlag, 281-288.

Mendgen K, Lange M, Bretschneider K. 1985. Quantitative estimation of the surface carbohydrates on the infection structures of rust fungi with enzymes and lectins. Archives of Microbiology 140: 307-311.

Mendgen K, Schneider A, Sterk M, Fink W. 1988. The differentiation of infection structures as a result of recognition events between some biotrophic parasites and their hosts. Fournal of Phytopathology 123: 259-272.

Mendgen K, Welter K, Scheffold F, Knauf-Beiter G. 1991. High pressure freezing of rust infected plant leaves. In Mendgen K, Lesemann DE, eds. Electron microscopy of plant pathogens. Heidelberg: Springer Verlag, 31-42.

Metzler B. 1982. Untersuchungen an Heterobasidiomyceten (23): Basidiosporenkeimung und Infektionsvorgang beim Birnengitterrost. Phytopathologische Zeitschrift 103: 126-138.

Mims CW, Richardson EA. 1989. Ultrastructure of appressorium development by basidiospore germlings of the rust fungus Gymnosporangium juniperi-virginianae. Protoplasma 148 : 111-119.

Mims CW, Taylor J, Richardson EA. 1989. Ultrastructure of the early stages of infection of peanut leaves by the rust fungus Puccinia arachidis. Canadian fournal of Botany 67: 3570-3579.

Morrall RAA, Duczek LJ, Sheard JW. 1972. Variations and correlations within and between morphology, pathogenicity, and pectolytic enzyme activity in Sclerotinia from Saskatchewan. Canadian Yournal of Botany 50: 767-786.

Mould MJR, Boland GJ, Robb J. 1991 a. Ultrastructure of the Colletotrichum trifolii-Medicago sativa pathosystem. I. Prepenetration events. Physiological and Molecular Plant Pathology, 179-178.

Mould RJM, Boland GJ, Robb J. 1991 b. Post penetration events. Physiological and Molecular Plant Pathology 38: 195-210.

Nicholson RL, Epstein L. 1991. Adhesion of Fungi to the Plant Surface: Prerequisite for Pathogenesis. In: Cole GT, Hoch $\mathrm{HC}$, eds. The fungal spore and disease initiation in plants and animals. New York: Plenum Press, 3-23.

Nicholson RL, Yoshioka H, Yamaoka N, Kunoh H. 1988. Preparation of the infection court by Erysiphe graminis. II. Release of esterase enzyme from conidia in response to a contact stimulus. Experimental Mycology 12: 336-349.

O'Connell RJ. 1987. Absence of a specialized interface between intracellular hyphae of Colletotrichum lindemuthianum and cells of Phaseolus vulgaris. New Phytologist 107: 725-734.

O'Connell RJ. 1991. Cytochemical analysis of infection structures of Colletotrichum lindemuthianum using fluorochrome-labelled lectins. Physiological and Molecular Plant Pathology 39: 189-200.

O'Connell RJ, Bailey JA. 1991. Hemibiotrophy in Colletotrichum lindemuthianum. In: Mendgen K, Lesemann D-E, eds. Electron microscopy of plant pathogens. Berlin: Springer Verlag, 211-222.

O'Connell RJ, Bailey JA, Richmond DV. 1985. Cytology and physiology of infection of Phaseolus vulgaris by Colletotrichum lindemuthianum. Physiological Plant Pathology 27: 75-98.

O'Connell RJ, Bailey JA, Vose IR, Lamb CJ. 1986. Immunogold labelling of fungal antigens in cells of Phaseolus vulgaris infected by Colletotrichum lindemuthianum. Physiological and Molecular Plant Pathology 28: 99-105.

O'Connell RJ, Nash C, Bailey JA. 1992. Lectin cytochemistry: a new approach to understanding cell differentiation, pathogenesis and taxonomy in Colletotrichum. In: Teger MJ, Bailey JA, eds. Colletotrichum: biology, pathology and control. CAB International

O'Connell RJ, Ride JP. 1990. Chemical detection and ultrastructural localization of chitin in cell walls of Colletotrichum lindemuthianum. Physiological and Molecular Plant Pathology 37: $39-53$.

Odermatt M, Röthlisberger A, Werner C, Hohl HR. 1988. 
Interactions between agarose-embedded plant protoplasts and germ tubes of Phytophthora. Physiological and Molecular Plant Pathology 33: 209-220.

Opel H, Schmidt HB, Wolfgang H. 1986. Beiträge zur Biologie des Gelbrostes (Puccinia striiformis West.) auf Gerste, I. Sporenkeimung und Penetration. Zentralblatt Mikrobiologie 141: 187-194.

Pascholati SF, Deising H, Leite B, Anderson D, Nicholson RL. 1993. Cutinase and non-specific esterase activities in the conidial mucilage of Colletotrichum graminicola. Physiological and Molecular Plant Pathology (in the press).

Pascholati SF, Yoshioka H, Kunoh H, Nicholson RL. 1992. Preparation of the infection court by Erysiphe graminis f. sp. hordei: Cutinase is a component of the conidial exudate. Physiological and Molecular Plant Pathology 41 : 53-59.

Pérez Artés E, Tena M. 1990. Purification and characterization of pectic enzymes from two races of Fusarium oxysporum $\mathrm{f}$. sp. ciceri differing in virulence to chickpea (Cicer arietinum L.). Physiological and Molecular Plant Pathology 37: 107-124.

Podila GK, Dickman MB, Kolattukudy PE. 1988. Transcriptional activation of a cutinase gene in isolated fungal nuclei by plant cutin monomers. Science 242 922-925.

Politis DJ, Wheeler H. 1973. Ultrastructural study of penetration of maize leaves by Colletotrichum graminicola. Physiological Plant Pathology 3: 465-471.

Porter FM. 1969. Protease, cellulase, and differential localization of endo- and exopolygalacturonase in conidia and conidial matrix of Colletotrichum orbiculare. Phytopathology 59: 1209-1213.

Ramadoss CS, Uhlig J. 1985. Composition of the mucilaginous spore matrix of Colletotrichum graminicola, a pathogen of corn, sorghum, and other grasses. Fournal of Agricultural and Food Chemistry 33: 728-732.

Read ND. 1991. Low-temperature scanning electron microscopy of fungi and fungus-plant interactions. In: Mendgen $\mathrm{K}$, Lesemann D-E, eds. Electron microscopy of plant pathogens. Berlin: Springer Verlag, 17-29.

Read ND, Kellock LJ, Knight H, Trewavas AJ. 1992. Contact sensing during infection by fungal pathogens. In: Callow JA, Green JR, eds. Perspectives in plant cell recognition. Cambridge: Cambridge University Press, 137-172.

Rexová-Benková L, Markovic O. 1976. Pectic enzymes. Advances in Carbohydrate Chemistry and Biochemistry 33: 323-385.

Riou C, Freyssinet G, Fevre M. 1991. Production of cell walldegrading enzymes by the phytopathogenic fungus Sclerotinia sclerotiorum. Applied and Environmental Microbiology 57: $1478-1484$.

Roberson RW. 1992. The actin cytoskeleton in hyphal cells of Sclerotium rolfsii. Mycologia 84 : 41-51.

Scott-Craig JS, Panaccione DG, Cervone F, Walton JD. 1990. Endopolygalacturonase is not required for pathogenicity of Cochliobolus carbonum on maize. The Plant Cell 2: 1191-1200.

Shaykh M, Soliday C, Kolattukudy PE. 1977. Proof for the production of cutinase by Fusarium solani f. sp. pisi during penetration into its host, Pisum sativum. Plant Physiology 60 : $170-172$.

Smart MG. 1991. The plant cell wall as a barrier to fungal invasion. In: GT, H, Cole $\mathrm{HC}$, eds. The fungal spore and disease initiation in plants and animals. New York, London: Plenum Press, 47-66.

Smith G. 1990. The haustoria of the Erysipheae. Botanical Gazette 29: 153-184.

Snetselaar KM, Mims CW. 1992. Sporidial fusion and infection of maize seedlings by the smut fungus Ustilago maydis. Mycologia 84: 193-203.

Snyder BA, Nicholson RL. 1988. Nuclease activity in the extracellular spore matrix of Colletotrichum spp. Phytopathology 78: 1588 (Abstr.)

Sock J, Rohringer R, Kang Z. 1990. Extracellular B-1, 3glucanases in stem rust-infected and abiotically stressed wheat leaves. Plant Physiology 94 : 1376-1389.

Soliday CL, Flurkey WH, Okita TW, Kolattukudy PE. 1984. Cloning and structure determination of cDNA for cutinase, an enzyme involved in fungal penetration of plants. Proceedings of the National Academy of Sciences of the U.S.A. 81 : 3939-3943.
Stahl DJ, Schäfer W. 1992. Cutinase is not required for fungal pathogenicity on pea. The Plant Cell 4: 621-629.

Staples R, Hoch HC, Epstein L, Lacetti L, Hassouna S. 1985. Recognition of host morphology by rust fungi: responses and mechanisms. Canadian Fournal of Plant Pathology 7: 314-322.

Staub T, Dahmen H, Schwinn FJ. 1974. Light and scanning electron microscopy of cucumber and barley powdery mildew on host and nonhost plants. Phytopathology 64: 364-372.

Stumpf MA, Leinhos ME, Staples RC, Hoch HC. 1991. The effect of $\mathrm{pH}$ and $\mathrm{K}^{+}$on appressorium formation by Uromyces appendiculatus urediospore germlings. Experimental Mycology 43: $356-360$.

Suzuki K, Furusawa I, Ishida N, Yamamoto M. 1982. Chemical dissolution of cellulose membranes as a prerequisite for penetration from appressoria of Colletotrichum lagenarium. Fournal of General Microbiology 128: 1035-1039.

Suzuki K, Furusawa I, Yamamoto M. 1983. Role of chemical dissolution of cellulose membranes in the appressorial penetration by Colletotrichum lagenarium. Annals of the Phytopathological Society of Japan 49: 481-487.

Swann EC, Mims CW. 1991. Ultrastructure of freeze-substituted appressoria produced by aeciospore germlings of the rust fungus Arthuriomyces peckianus. Canadian Fournal of Botany 69: $1655-1665$.

Sweigard JA, Chumley FG, Valent B. $1992 a$. Cloning and analysis of CUT1, a cutinase gene from Magnaporthe grisea. Molecular and General Genetics 232: 174-182.

Sweigard JA, Chumley FG, Valent B. $1992 b$. Disruption of a Magnaporthe grisea cutinase gene. Molecular and General Genetics 232: 183-190.

Takahashi K, Aist JR, Israel HW. 1985. Distribution of hydrolytic enzymes at barley powdery mildew encounter sites: implications for resistance associated with papilla formation in a compatible system. Physiological Plant Pathology 27 : 167-184.

Taylor J, Mims CW. 1991. Fungal development and host cell responses to the rust fungus Puccinia substriata var. indica in seedling and mature leaves of susceptible and resistant pearl millet. Canadian Yournal of Botany 69: 1207-1219.

Tenhaken R, Barz W. 1991. Characterization of pectic enzymes from the chickpea pathogen Ascochyta rabiei. Zeitschrift für Naturforschung 46c: 51-57.

Toubart P, Desiderio A, Salvi G, Cervone F, Daroda L, DeLorenzo G. 1992. Cloning and characterization of the gene encoding the endopolygalacturonase-inhibiting protein (PGIP) of Phaseolus vulgaris L. The Plant Fournal 2: 367-373.

Uchiyama T, Ogasawara N, Nanba Y, Ito H. 1979. Conidial germination and appressorial formation of the plant pathogenic fungi on the coverglass or cellophane coated with various lipid components of plant leaf waxes. Agricultural and Biological Chemistry 43: 383-384

Urbanek 1989. The role of cutinase and cell wall degrading enzymes produced by Fusaria in pathogenesis. In: Chelkowski $\mathrm{J}$, ed. Fusarium: mycotoxins, taxonomy and pathogenicity. Amsterdam, Oxford, New York, Tokyo: Elsevier, 243-256.

Valsangiacomo C, Gessler C. 1992. Purification and characterization of an exo-polygalacturonase produced by Venturia inaequalis, the causal agent of apple scab. Physiological and Molecular Plant Pathology 40: 63-77.

Van Dyke CG, Mims CW. 1991. Ultrastructure of conidia, conidium germination, and appressorium development in the plant pathogenic fungus Colletotrichum truncatum. Canadian Fournal of Botany 69: 2455-2467.

Van Sumere CF, Van Sumere-De Preter C, Ledingham GA. 1957. Cell-wall splitting enzymes of Puccinia graminis var. tritici. Canadian Fournal of Microbiology 3: 761-770.

Waterhouse W. 1921. Infection of Berberis vulgaris by sporidia of Puccinia graminis. Annals of Botany 35: 557-564.

Welter K, Müller M, Mendgen K. 1988. The hyphae of Uromyces appendiculatus within the leaf tissue after high pressure freezing and freeze substitution. Protoplasma 147: 91-99.

Wessels JGH. 1990. Role of cell wall architecture in fungal tip growth generation. In: Heath IB, ed. Tip growth in plant and fungal cells. San Diego: Academic Press, Inc., 1-29.

Wheeler H. 1975. Plant pathogenesis. Berlin, Heidelberg, New York: Springer Verlag. 
Wijesundera RLC, Bailey JA, Byrde RJW, Fielding AH. 1989. Cell wall degrading enzymes of Colletotrichum lindemuthianum: their role in the development of bean anthracnose. Physiological and Molecular Plant Pathology 34: 403-413.

Wolkow PM, Sisler HD, Vigil EL. 1983. Effect of inhibitors of melanin biosynthesis on structure and function of appressoria of Colletotrichum lindemuthianum. Physiological Plant Pathology 22: $55-71$.

Woloshuk CP, Kolattukudy PE. 1986. Mechanism by which contact with plant cuticle triggers cutinase gene expression in the spores of Fusarium solani f. sp. pisi. Proceedings of the National Academy of Sciences of the U.S.A. 83: 1704-1708.

Woloshuk CP, Sisler HD, Vigil EL. 1983. Action of the antipenetrant, tricyclazole, on appressoria of Pyricularia oryzae. Physiological Plant Pathology 22: 245-259.

Wood RKS. 1976. Physiological plant pathology. Oxford: Blackwell.

Wösten HAB, Moukha SM, Sietsma JH, Wessels JGH. 1991. Localization of growth and secretion of proteins in Aspergillus niger. Fournal of General Microbiology 137: 2017-2023.
Xu H, Mendgen K. 1991. Early events in living epidermal cells of cowpea and broad bean during infection with basidiospores of the cowpea rust fungus. Canadian Fournal of Botany 69: $2279-2285$

Xuei XL, Järlfors U, Kuć J. 1988. Ultrastructural changes associated with induced systemic resistance of cucumber to disease: host response and development of Colletotrichum lagenarium in systemically protected leaves. Canadian fournal of Botany 66: 1028-1038.

Yazdi MT, Woodward JR, Radford A. 1990. Cellulase production by Neurospora crassa: The enzymes of the complex and their regulation. Enzyme Microbiology and Technology 12: $116-119$.

Young DH, Kauss H. 1984. Adhesion of Colletotrichum lindemuthianum spores to Phaseolus vulgaris hypocotyls and to polystyrene. Applied and Environmental Microbiology 47: 616-619.

Zhou X-L, Stumpf MA, Hoch HC. 1991. A mechanosensitive channel in whole cells and in membrane patches of the fungus Uromyces. Science 253: 1415-1417. 